Savjetovanje s dionicima u primjeni najboljih praksi u održivom planiranju agregata

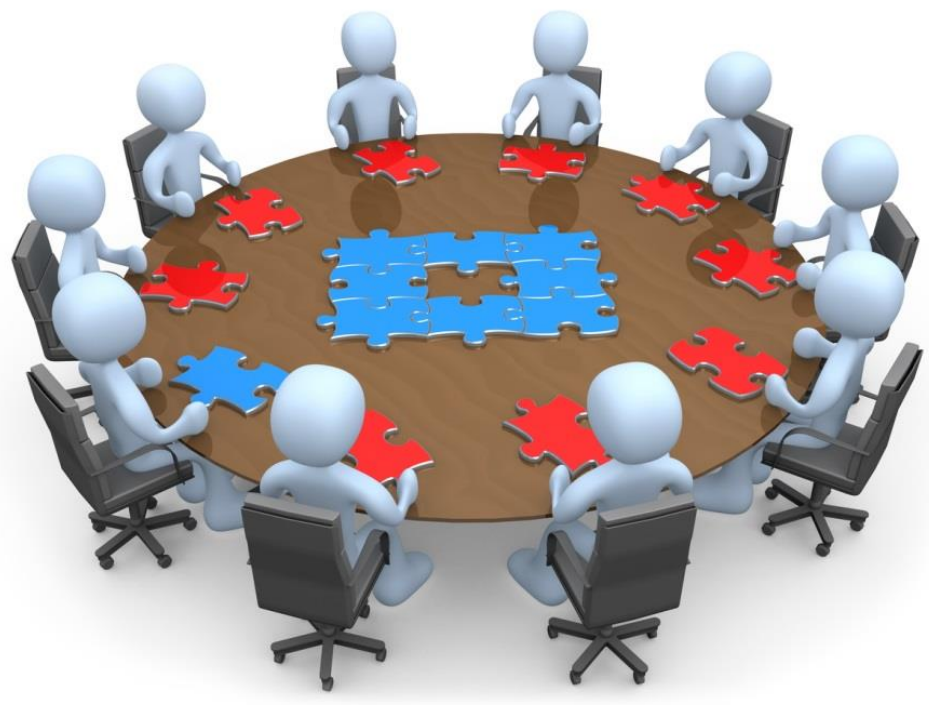

Prosinac 2014

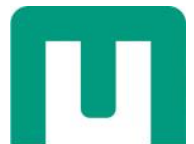

MONTAN UNIVERSITÄT WWW.UNILEOBEN.AC.AT

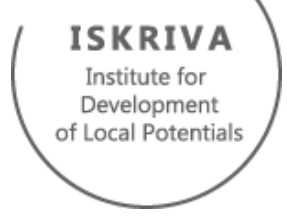





\section{Savjetovanje s dionicima u primjeni najboljih praksi \\ u održivom planiranju agregata}

\section{Temeljeno na:}

radu i iskustvu sudionika u okviru Radnog paketa 3 projekta SNAP-SEE "Održivo planiranje kamenih agregata u jugoistočnoj Europi" (SEE/D/0167/2.4/X)

\section{Web stranica: http://www.snapsee.eu}

Ostvareno u Aktivnosti 3.3: Podloga za savjetovanje s dionicima: Priručnik o jačanju kapaciteta i uključivanje dionika u postupak planiranja agregata

\section{Informacije o nakladniku}

Izdanje i priprema:

Dizajn naslovnice:

Tisak:

Godina izdanja:
Foteini Stathogianni, Urška Dolinar

Stelios Mavrigiannakis

Hrvatski geološki institut

2014

Prijevod i prilagodba na hrvatski jezik:

Žic, Mirela, bacc. oec., Hrvatski geološki institut (HGI), Hrvatska

Dedić Željko, dipl. ing., Hrvatski geološki institut (HGI), Hrvatska

Lektorirao:

Peh, Zoran, dr. sc., Hrvatski geološki institut (HGI), Hrvatska

\section{Odricanje od odgovornosti}

Ova SNAP-SEE publikacija odražava samo mišljenje autora te Upravno tijelo Programa za transnacionalnu suradnju u jugoistočnoj Europi ne preuzima odgovornost za bilo kakve moguće radnje temeljene na informacijama sadržanima u njoj. CSNAP-SEE projekt 2014 
Dolinar, Urška, MBA, Iskriva, institute for development of local potentials, Slovenija

Softić, Mateja, Iskriva, institute for development of local potentials, Slovenija

Kozinc, Zdravko, Iskriva, institute for development of local potentials, Slovenija

\section{Partner voditelj projekta}

Montanuniversität Leoben (Sveučilište Leoben), Austrija

\section{Recenzenti}

\begin{tabular}{ll}
\hline Ime & Institucija \\
\hline Shields, Deborah J., Dr. & University of Leoben, Austrija \\
O'Brien, Jim & Former President of the European Aggregates Association, Irska
\end{tabular}

\section{Identifikator digitalnog objekta (DOI):}

doi: 10.5474/snapsee-WP3-HR

\section{Priznanje}

Partneri projekta SNAP-SEE zahvaljuju Europskoj komisiji na financiranju ovog projekta koji je doveo do plodne suradnje među partnerima koji dijele slične probleme i zajedničku viziju te omogućio razvoj ovog priručnika.

\section{Citiranje}

Ovaj priručnik se u bibliografiji citira na sljedeći način: Dolinar U., Softic M .i Z. Kozinc (2014), Priručnik o savjetovanju s dionicima u primjeni najboljih praksi u održivom planiranju agregata, SNAP-SEE, 2014, doi:10.5474/snapsee-WP3-HR 
Predgovor

$1 \quad$ Uvodne informacije $\quad 7$

1.1 Svrha priručnika 8

1.2 Struktura priručnika 9

1.3 Planiranje agregata kao dio javnog političkog ciklusa 10

$2 \quad$ Osnovna načela uključivanja dionika $\quad 11$

2.1 Razlozi sudjelovanja 12

2.2 Prednosti uspješnog sudjelovanja 13

2.3 Načini uključivanja dionika 14

$3 \quad$ Planiranje postupka sudjelovanja $\quad 17$

3.1 Prije početka 18

3.2 Koraci u planiranju postupka sudjelovanja 18

3.3 Svrha i koraci u postupku sudjelovanja 19

3.4 Vremenski period za određivanje postupka sudjelovanja 23

$4 \quad$ Tko su dionici i kako ih uključiti $\quad 25$

4.1 Prepoznavanje dionika u planiranju agregata 26

$\begin{array}{lll}4.2 & \text { Grupiranje dionika prema ulogama } & 27\end{array}$

$5 \quad$ Planiranje događanja s dionicima $\quad 31$

5.1 Vrijeme potrebno za organiziranje događanja 32

5.2 Tko je u mome timu 33

5.3 Odabrati pravo vrijeme i mjesto događanja 34

5.4 Svrha događanja 35

$5.5 \quad$ Kako strukturirati događanje 36

5.5.1 Općenite prezentacije 36

5.5.2 Prezentacije o jačanju kapaciteta 36

5.5.3 Moderirana rasprava 37

5.5.4 Radionica s aktivnim sudjelovanjem sudionika 38

5.6 Priprema dnevnog reda i pozivnica $\quad 40$

$\begin{array}{lll}\text { 5.6.1 Dnevni red događanja } & 40\end{array}$ 
$\begin{array}{lll}5.6 .2 & \text { Pozivnice } & 42\end{array}$

$\begin{array}{lll}5.7 & \text { Detaljan plan događanja } & 43\end{array}$

$6 \quad$ Tehnike za interaktivne radionice $\quad 45$

$\begin{array}{lll}6.1 & \text { Prije početka } & 46\end{array}$

6.2 Podjela sudionika u skupine 46

$\begin{array}{lll}6.3 & \text { Vrtuljak ideja } & 47\end{array}$

6.4 "World Café" 48

$7 \quad$ Provedba događanja $\quad 49$

7.1 Pregled događanja i informiranje tima 50

7.2 Pripremanje dvorane 50

7.3 Za vrijeme održavanja događanja

7.4 Moderiranje i moderatori 51

7.5 Završetak događanja

$8 \quad$ Nakon događanja - naknadne aktivnosti 53

9 Zaključci i preporuke $\quad 55$

$10 \quad$ Literatura $\quad 59$ 


\section{Predgovor}

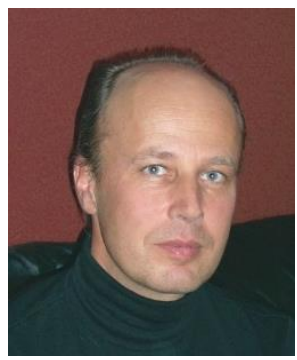

Države jugoistočne Europe (JIE) bogate su građevinskim agregatima, tj. drobljenim kamenom, šljunkom, pijeskom i ostalim zrnatim inertnim materijalima koji se koriste $u$ građevinskoj industriji; međutim, ovi resursi nisu ravnomjerno raspoređeni zbog čega ih $u$ pojedinim područjima ima $u$ izobilju, a u drugim ih nedostaje. Nadalje, pristup resursima postaje iznimno težak zbog razvoja drugih infrastruktura te pritisaka na okoliš. Kako su kameni agregati teški i glomazni, a transport je skup, pristup lokalnim resursima ključan je za tržište. Regija JIE će vjerojatno zahtjevati 50\% veću proizvodnju agregata do 2020 kako bi zadovoljila rastuću potrebu za infrastrukturom.

Stoga, postoji potreba prebaciti se na održivo gospodarenje kamenim agregatima (SARMa) te je potrebno omogućiti održivu mješovitu opskrbu (SSM) agregata u regiji kako bi se povećala učinkovitost resursa i podržao održivi razvoj. SARMa je učinkovito gospodarenje eksploatacijom i otpadom niskog socio-ekološkog utjecaja, povezano s visokim angažmanom dionika. SSM se sastoji od agregata iz različitih izvora, uključujući reciklirani građevinski otpad i industrijske nusproizvode (šljaka), kao i primarnih materijala proizvedenih kako na domaćem tržištu tako i u inozemstvu, koji zajedno povećavaju svu dobit opskrbe agregata kroz generacije.

Primjenjivanje SARM-a i SSM-a zahtjeva okvir za planiranje i podršku politike. Zbog regionalnih razlika i povijesnog razvoja, pristup politici agregata, planiranju i gospodarenju razlikuje se na raznim političkim razinama diljem JI Europe i rijetko se podudara. Izazovi uključuju pravila i planove koji utječu na gospodarenje i opskrbu agregatima, a podijeljeni su između mnogo različitih zakonskih dokumenata, što otežava koordinaciju i razumijevanje. Također, postoji nedostatak koordinacije u planiranju nabave primarnih i sekundarnih agregata. Jl Europa nema dovoljno podataka za podršku u planiranju agregata, nema dovoljne kapacitete i stručnost za planiranje primarnih ili sekundarnih agregata, niti su dionici dovoljno uključeni u razvoj plana gospodarenja agregatima. Projekt SNAP-SEE bavi se tim nedostacima kako bi potaknuo razvoj aktivne, odgovorne i održive industrije agregata u regiji J Europi.

Specifična svrha projekta SNAP-SEE bila je stvoriti i primijeniti Alate za planiranje agregata kako bi se pomoglo vlastima i dionicima Jl Europi u suradnji oko unaprjeđivanja postupka planiranja i gospodarenja agregatima. SNAP-SEE se nadovezuje na rezultate projekta održivog gospodarenja kamenim agregatima (SARMa), prethodnog projekta financiranog iz fonda transnacionalne suradnje JI Europe (http://www.sarma.eu). SNAP-SEE je financiran od strane "EU South East 
Europe (SEE) Transnational Cooperation Programme" (SNAP-SEE, SEE/D/0167/2.4/X) i ima 27 partnera iz 12 država JI Europe i Turske. Partner voditelj projekta bio je Sveučilište Leoben, Austrija. SNAP-SEE je bio dvogodišnji projekt koji je završio u studenom 2014. godine.

SNAP-SEE Alati za planiranje agregata sastoje se od 4 proizvoda koji su povezani i međusobno se podržavaju.

\section{Vizija najboljih praksi za planiranje agregata u jugoistočnoj Europi}

Dokument "Najbolje prakse" predstavlja viziju prijelaza prema integriranom i razumljivom održivom planiranju u Jl Europi. On uključuje diskusije o problemima kojima se treba posvetiti, međukorake koji se mogu napraviti prema još boljem održivom planiranju i pregled dijelova koje bi trebao sadržavati održivi plan.

2. Kako izraditi Održivi plan agregata

Dokument "Kako" predstavlja kartu za planiranje, uključujući diskusije za sam proces planiranja i njegove razne korake. Priloženi su primjeri dobro napisanih modula za planiranje koji sadrže principe, pristupe i radnje potrebne za postizanje ciljeva vizije koja je predstavljena u izvješću "Najbolje prakse".

3. Savjetovanje s dionicima kod primjene najboljih praksi u održivom planiranju agregata

Dokument "Savjetovanje" sadrži priručnik koji, korak po korak, objašnjava planiranje i provođenje savjetovanja dionika kako bi se osiguralo da industrija, vlada, nevladine organizacije i civilno društvo mogu dati mišljenje i sudjelovati u procesu planiranja. Također je predviđen i materijal za jačanje kapaciteta.

4. Podaci i analize koji podržavaju najbolje prakse u održivom planiranju agregata Ovaj dokument govori o različitim tipovima podataka koji daju osnovne pozadinske informacije u procesu planiranja. Dokument se bavi definicijom, značajem, dostupnosti, strukturom i potrebama navedenih podataka. Predstavljaju se metode za potvrđivanje i analiziranje podataka, uključujući i pristupe prognoziranju potražnje.

Koordinator projekta

Guenter Tiess

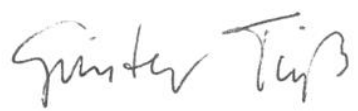

Montanuniversität Leoben (Sveučilište Leoben) 


\section{Uvodne informacije}

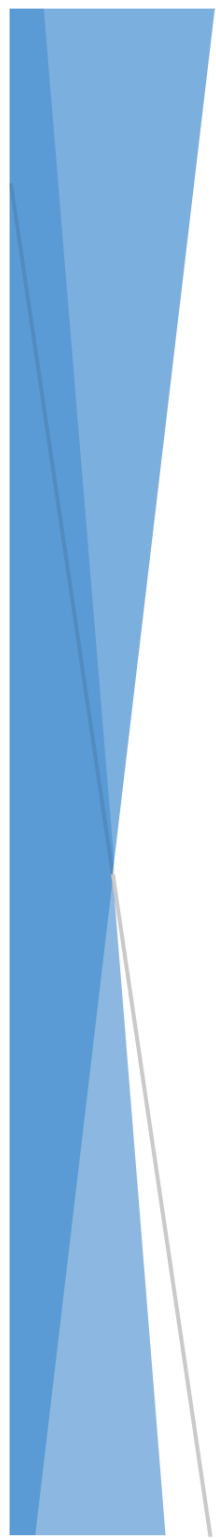

Planiranje opskrbe agregatima, kao dio politike planiranja mineralnih sirovina, rudarstva i zaštite okoliša, je odgovornost državnih, regionalnih i/ili lokalnih vlasti. Kako bi se osiguralo učinkovito planiranje ključno je savjetovati se $s$ ciljanim skupinama koje su uključene ili na njih utječe politika $i$ industrija agregata, odnosno s dionicima. Također je važno savjetovati se i s državnim agencijama i službama na svim razinama, predstavnicima industrije, akademskom zajednicom i stručnjacima te nevladinim organizacijama $i$ građanskim društvom.

Kada se u postupke odlučivanja uključuju dionici, mogući su različiti pristupi, od informiranja do zajedničkog odlučivanja. Izbor pristupa ovisi o ciljevima postupka i nositelja postupka.

Ovaj priručnik daje uvid u savjetovanje s dionicima kao pratećoj aktivnosti te kada se primjenjuju najbolje prakse u planiranju agregata na nacionalnoj, regionalnoj ili lokalnoj razini. Pokazuje nam prednosti pristupa sa sudjelovanjem $i$ daje korisne savjete o tome kako odrediti ciljeve uključivanja dionika te kako praktično planirati i organizirati događanja u vezi sa savjetovanjem. 


\subsection{Surha priručnika}

Planiranje agregata odnosi se na niz državnih politika kojima je namjena osigurati postojanu opskrbu agregata koji su potrebni za cjelokupnu izgradnju u državi ili regiji, od zgrada do infrastrukture. Primarni agregati su uglavnom pijesak, šljunak i tehničko-građevni kamen (drobljeni kamen); sekundarni agregati mogu biti reciklirani građevinski otpad, proizvedeni agregati, iskopani materijal iz građevinskih radova, itd.

Politike planiranja agregata su proglašene državnim ciljevima u području agregata; planiranje je stvaranje formalnih postupaka koje treba slijediti kako bi se postigli zadani ciljevi; gospodarenje je primjena planova. Projekt SNAP-SEE - Održivo planiranje kamenih agregata u jugoistočnoj Europi (JIE) bavi se ključnim pitanjem: kako države Jl Europe i regije mogu unaprijediti svoj postupak planiranja agregata, integrirati planiranje primarnih i sekundarnih agregata kako bi povećali učinkovitost resursa i podigli razinu kapaciteta državnih tijela, industrije i civilnog društva u odnosu na gospodarenje, planiranje i opskrbu agregatima.

Stoga, jedan od ključnih ciljeva je povećati kapacitete javnopravnih tijela za prostorno planiranje kako bi postali svjesni ovih problema te povećati uključenost dionika u postupak planiranja i provođenja. Dionici su "ljudi ili organizacije na koje se utječe ili koji će imati utjecaj na program, projekt ili aktivnost" (EC Guidance, 2010). Prema tome, uključivanje dionika može obuhvaćati niz različitih aktivnosti od strane raznih tijela, skupina ili pojedinaca, od davanja informacija ili prikupljanja mišljenja do zajedničkog donošenja odluka.

Svrha ovog priručnika je pružiti praktične savjete:

$\checkmark \quad$ kako povećati kapacitet ciljnih skupina povezanih s planiranjem agregata;

$\checkmark \quad$ kako prepoznati različite skupine dionika i odgovarajuće tehnike za njihovo uključivanje;

$\checkmark \quad$ kako planirati postupak savjetovanja;

$\checkmark \quad$ kako provesti postupak savjetovanja i događanje; te

$\checkmark \quad$ koje se metode i tehnike mogu koristiti pri savjetovanju i povećanju kapaciteta.

Detaljne smjernice o planiranju agregata dostupne su u prvom proizvodu Alata za planiranje agregata, Vizija najboljih praksi za planiranje agregata u jugoistočnoj Europi. Ovaj „alat" pruža opće informacije o planiranju mineralnih sirovina i dokumentaciju te prikazuje sadržaj dokumentacije za planiranje i metode planiranja 
Primarna ciljna skupina ovog priručnika su političari $i$ dužnosnici državnih, regionalnih $i$ lokalnih vlasti te tijela iz svih sektora povezanih s planiranjem agregata, uključujući sektor rudarstva i eksploatacije, građevinarstva, gospodarstva, okoliša, gospodarenja otpadom, prostornog planiranja, vode, prijevoza, itd.

Sekundarne ciljne skupine su svi dionici koji su uključeni ili pogođeni planiranjem agregata i aktivnostima upravljanja, od stručnjaka, predstavnika industrije do lokalnih zajednica i nevladinih organizacija (NVO).

\subsection{Struktura priručnika}

Priručnik predstavlja kombinaciju teorijske pozadine i praktičnih savjeta temeljenih na iskustvu projekta SNAP-SEE. Poglavlje 2 objašnjava ključne prednosti i načela sudjelovanja i angažmana različitih ciljnih skupina u planiranju. Poglavlja 3-8 su orijentirana prema praktičnoj primjeni $i$ pružaju savjet kada se netko suoči $s$ izazovom organiziranja postupka savjetovanja koji se sastoji od niza različitih aktivnosti i događanja. Uključeni su različiti savjeti i prikazani predlošci tabela za planiranje događanja. Općeniti predlošci dostupni su za preuzimanje na http://snapsee.eu/. Cilj smjernica i predložaka je da vas vode kroz postupak planiranja sudjelovanja i pomažu vam razmotriti različite aspekte koji se moraju uzeti u obzir. Preporuke su sažete u poglavlju 9. Slika 1.1 prikazuje strukturu priručnika, tj. osnovne korake u planiranju uključivanja dionika.

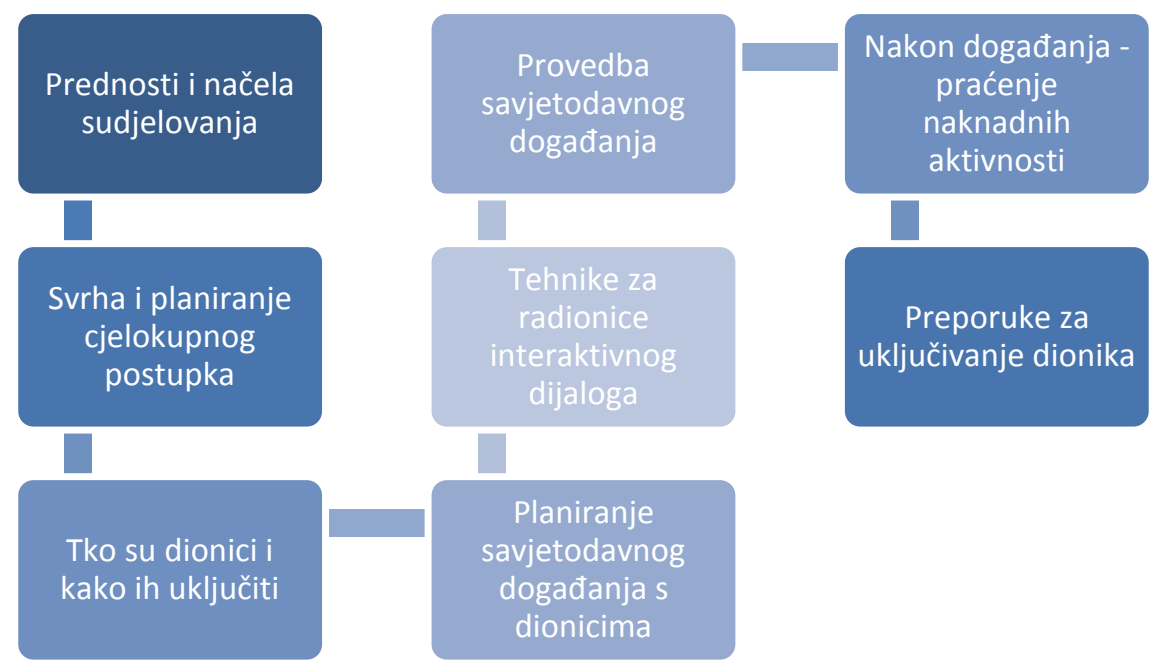

Slika 1.1: Ključni koraci u planiranju uključivanja dionika 


\subsection{Planiranje agregata kao dio političkog ciklusa}

Svaka javna politika stvorena je kako bi odgovorila na potrebe iz određenih područja. Politika planiranja agregata odgovara na potrebe društva za građevinskim mineralnim sirovinama. Politika planiranja agregata prati faze ciklusa javne politike kako je prikazano na slici 1.2. Svrha unaprjeđivanja politike uglavnom se može podijeliti u nekoliko faza - od identificiranja trenutne situacije, do analize dobrih praksi i uskih grla, što rezultira prijedlogom preporuka i plana djelovanja za praktičnu primjenu preporuka, i praćenja rezultata.

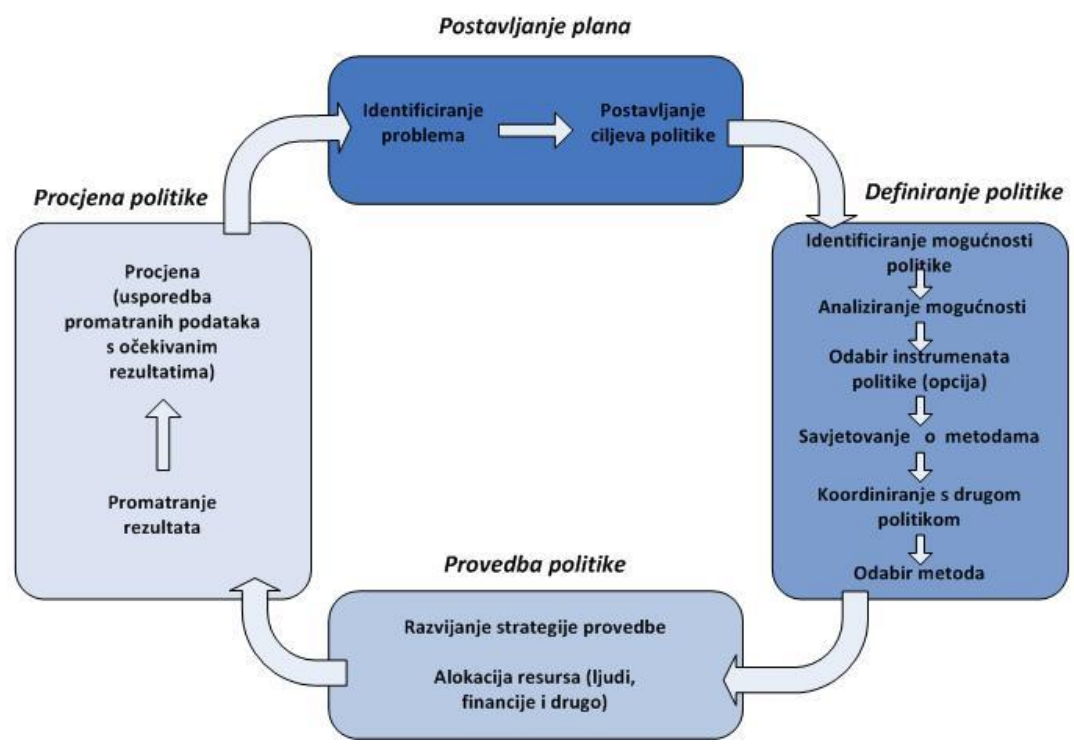

Slika 1.2: Ciklus javne politike

(http://www.mfe.govt.nz/publications/rma/drafting-issues-jul03/html/page2.html)

Da budemo precizniji, politika planiranja agregata dio je državne (i/ili regionalne) politike mineralnih sirovina. Politika mineralnih sirovina može biti objavljena kao jedan krovni dokument (npr. Austrijski plan mineralnih sirovina), ali mnogo češće se razlaže kroz nekoliko dokumenata iz raznih područja koje su u nadležnosti nacionalne i/ili lokalne samouprave (zakoni i propisi o rudarstvu i eksploataciji, okoliš, gospodarenje otpadom, gospodarenje vodama itd.), što znači da ne postoji jedinstven pristup. Savjetovanje s dionicima može se provesti u bilo kojoj fazi političkog ciklusa, s ciljem vrednovanja trenutnog stanja te predlaganjem rješenja $i$ unapređenja. Savjetovanja se moraju prilagoditi fazi političkog ciklusa i njihova svrha mora biti jasno definirana. Preporuka je započeti savjetovanje $s$ dionicima $u$ što ranijoj fazi. 


\section{Osnovna načela uključivanja dionika}

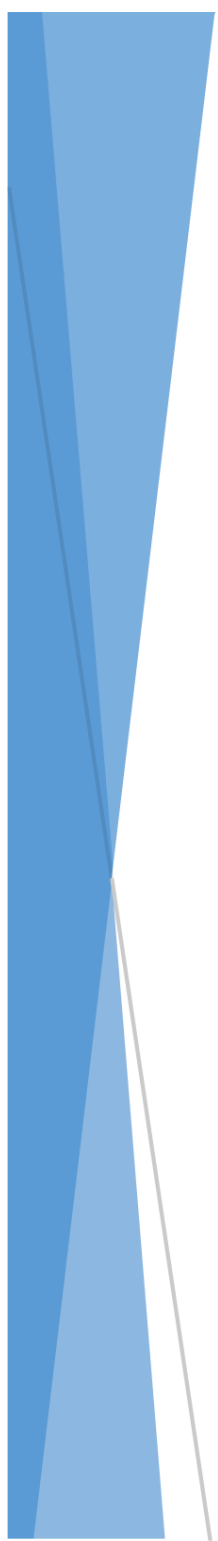

U usporedbi s tradicionalnim javnim pristupom savjetovanja kada mala grupa ljudi donosi odluke i kasnije ih objašnjava javnosti, povezani pristup uključenju ima nekoliko prednosti. Rezultat toga su odluke donesene na temelju dobrih informacija koje se lakše provode. Rješavaju se stvarni problemi, a pronalazak rješenja jamče sve uključene strane. Nakon svega, svi troškovi su smanjeni i mogu se očekivati trajne promjene.

Ovo poglavlje predstavlja razliku između tradicionalnih javnih rasprava i pristupa uključivanja dionika. Osim prednosti, također objašnjava različite načine uključivanja dionika i ključna načela njihova angažmana.

Savjetovanja koja se provode u projektu SNAP-SEE pokazala su brojne prednosti uključivanjem različitih dionika na način da sudjeluju u postupku planiranja: podijeljena su razna mišljenja, prepoznaju se bolja rješenja i poboljšana je suradnja između brojnih institucija. 


\subsection{Razlozi sudjelovanja}

Kada se raspravlja o važnim pitanjima za javnost, kao što su ona koja utječu na sljedećih 20 godina planiranja agregata i izgradnje te nekoliko srodnih industrija, obično se svi slažu da bi javnost trebala biti uključena u raspravu. Međutim, velika je razlika između tradicionalnog savjetovanja javnosti i dijaloga s dionicima.

Tradicionalno savjetovanje javnosti: obično manja grupa ljudi odlučuje što bi se trebalo dogoditi i tada o tome izvijesti ostale. Mnogo se vremena troši na objašnjavanje i opravdanje donesenih odluka. Širi krug dionika ima ograničenu mogućnost utjecaja na ono što je planirano i obično se $s$ njima savjetuje tek onda kada je većina odluka već donesena i zapisana. Primjena može biti dosta zahtjevna, posebno ako se smatra da neki interesi ili sektori nisu uzeti u obzir (Pound, 2008). Postupak traje duže i ima manju mogućnost pozitivnog ishoda.

Uključenost dionika (termini koji se također koriste u tekstu kao sinonimi: dijalog s dionicima/angažiranost/suradnički pristup/sudjelovanje javnosti): alternativa je od početka krenuti sa suradničkim pristupom. To znači angažiranje dionika odmah na početku dok su mogućnosti još otvorene i dok mogu utjecati na ishod. Svi dijele znanje i uvid. Istražuju se moguće radnje i ideje prije konačne odluke i zapisivanja. Korištenje znanja, pogleda i ideja šire grupe ljudi gradi društveni kapital, obogaćuje raspravu i vodi boljem ishodu (Pound, 2008). Više vremena troši se na dobru pripremu i interakciju s ljudima kojih se to tiče, što vodi do lakše provedbe dogovorenog ishoda (Creighton, 2005). Predstavnici različitih skupina dionika, uključujući kreatore i provoditelje politike, stručnjake, akademske zajednice, industriju, nevladin sektor i širu javnost, uključuju se u proces planiranja što ranije.

Sudjelovanje javnosti u donošenju odluka odnosi se na zahtjev da javnost mora biti obaviještena o svim bitnim projektima i mora imati priliku sudjelovati tijekom donošenja odluka i zakonodavnog procesa. Donositelji odluka mogu iskoristiti znanje i stručnost ljudi; ovaj doprinos je dobra prilika za poboljšanje kvalitete odluka o zaštiti okoliša, ishoda i garancija zakonodavne procedure.

Državna tijela dužna su poštovati sudjelovanje javnosti u donošenju odluka te pripremanju ili provedbi određenih planova i programa povezanih s okolišem prema Konvenciji Århus i Direktivi sudjelovanja javnosti (2003/35/EC).

Postupak sudjelovanja: postupak u kojem definiramo način uključivanja dionika u željeno područje sudjelovanja. Definiramo svrhu postupka, željeni ishod i rezultate, aktivnosti i broj događanja koje ćemo provesti, tko će sudjelovati, itd. Uključivanje 
dionika određeno je postupkom sudjelovanja, a njegovi koraci su objašnjeni u ovom priručniku.

Razlika koja se može napraviti uključivanjem dionika prikazana je na slici 2.1. Dobra priprema od početka će uštedjeti vrijeme i novac u budućnosti. Želimo polako prikupiti najbolje prijedloge i ideje kako bismo što učinkovitije usvojili najbolje prakse u politici planiranja opskrbe agregatima. Cilj nije samo priprema politike; bit ćemo uspješni tek onda kada provedemo dobro pripremljene politike. Stjecanjem šire suglasnosti osiguravamo da politike ne ostanu samo slovo na papiru nego i da ih koriste i provode svi uključeni. To znači pomak od stvaranja plana ili strategije u najkraćem vremenu prema fokusiranju na proces kojim je plan određen i kojim se osigurava da je prihvatljiv svima na koje će utjecati. To je pomak od odlučivanja za ljude prema odlučivanju s njima.

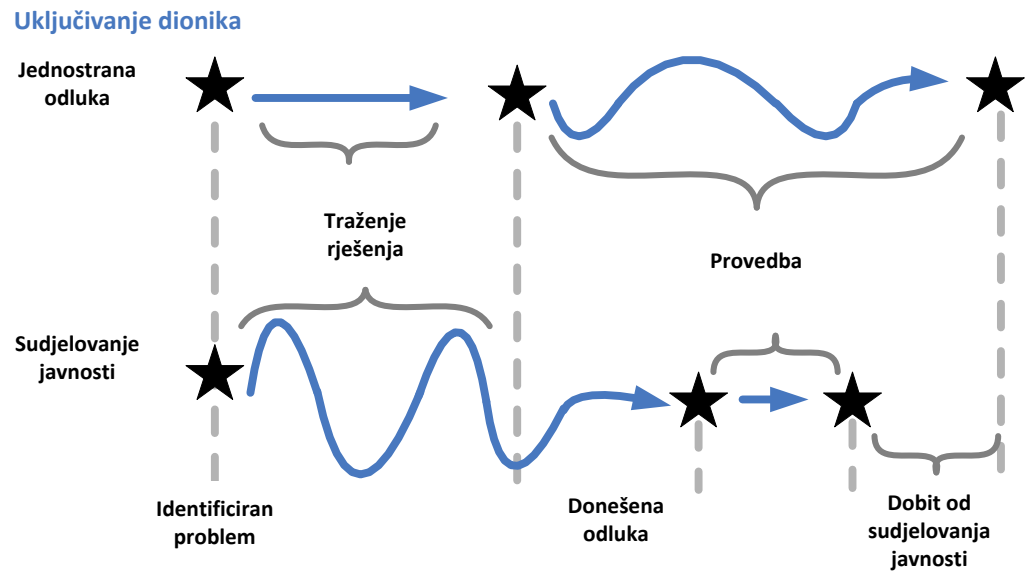

Slika 2.1: Razlika između tradicionalnog savjetovanja i uključivanja dionika (usvojeno prema Creighton-u, 2005)

\subsection{Prednosti uspješnog sudjelovanja}

Rezultat uspješnog sudjelovanja su prednosti za sve uključene strane. U konačnici, vodi do boljih odluka koje utječu na svačiju budućnost, što rezultira pozitivnim ishodom za sve kao i uštedom vremena i novca. Ključne prednosti postupka dobro isplaniranog i provedenog uključivanja dionika su:

$\checkmark$ Promišljene odluke: dobar postupak omogućuje prikupljanje različitih oblika znanja u planiranju agregata od strane sudionika: znanje, vještine (know-how), iskustvo, vrijednosti i opažanja. 
$\checkmark$ Trajne promjene: kada odlučivanje ili provedba programa uključuje i druge dionike u postupak donošenja odluka te oni zajedno odlučuju o potrebnim promjenama, više su motivirani osigurati pozitivne ishode i dugoročne prednosti za sve uključene strane.

$\checkmark \quad$ Vlasništvo: dobro proveden postupak ostvaruje kupovinu i aktivnu potporu u provedbi od svih uključenih strana.

$\checkmark$ Rješavanje stvarnih problema: uključivanjem dionika rješenja se zasnivaju na istraživanju stvarnih potreba i problema, a ne na pretpostavkama drugih. Rješenja se također procjenjuju kako bismo bili sigurni da neće uzrokovati novi niz problema za nekog drugog.

$\checkmark \quad$ Izbjegavanje ili upravljanje sukobom: uključivanjem dionika u ranoj fazi, kada su mogućnosti još otvorene i fleksibilne, moguće je identificirati potencijalni ili stvarni sukob i aktivno raditi na njegovom rješavanju.

$\checkmark$ Smanjeni troškovi: vođenje postupka sudjelovanja košta, ali se dugoročno isplati bržom i lakšom provedbom. Također štedi vrijeme i novac na troškovima promotivnog materijala i događanja, a može izbjeći znatne novčane $\mathrm{i}$ vremenske troškove te gubitak ugleda u pravnim postupcima (Pound, 2008).

Angažiranje dionika na način da sudjeluju je osnovno načelo u svim pothvatima tijekom postupka; to nije samo metoda ili tehnika koja se koristi za vrijeme događanja u određene svrhe. Načela i vrijednosti uključivanja dionika na kojima se temelji provedba (uključenost, transparentnost, otvorenost i jasnoća, neovisnost, predanost i odgovornost) treba uzeti u obzir u svakom koraku postupka sudjelovanja (Vijeće za zaštitu okoliša, 2004).

\subsection{Načini uključivanja dionika}

Postoje različiti načini uključivanja dionika u postupke planiranja, odlučivanja i provedbe koji utječu na opskrbu agregata. Možemo govoriti o: (a) razmjeni informacija, (b) prikupljanju informacija, (c) savjetovanju i (d) zajedničkom donošenju odluka. U ovom modelu, jedan pristup povezivanja s dionicima nije ništa bolji od drugog. Svaki ima svoje vrijednosti $\mathbf{i}$ pogodan je za različite namjene. Četiri kategorije temelje se na tome u kojoj mjeri dionici utječu na ishod; to nije kategoriziranje načina događanja. Moguće je u potpunosti provesti događanja u tri kategorije:

$\checkmark$ Prikupljanje informacija - gdje ljudi nemaju utjecaja na to kako se informacije koriste (npr., prikupljanje povratnih informacija putem upitnika);

$\checkmark$ Savjetovanje - gdje se njihova stajališta prosljeđuju onima koji donose odluke; ili

$\checkmark$ Zajedničko donošenje odluka - gdje direktno pomažu u donošenju odluka. 
Neovisno o tome koja se kategorija koristi, važno je da dionici razumiju što se od njih traži i da je jasno do koje mjere mogu utjecati na donošenje odluka. Odabrani način koji se odnosi na dionike treba odražavati svrhu postupka sudjelovanja. U jasnim i nekontroverznim situacijama može se koristiti priopćenje za javnost. U složenijim i/ili spornim situacijama ulaganje vremena i novca u dobro osmišljen dijalog može se pokazati odgovornim pristupom (Pound, 2008). Detalji svakog pristupa su prikazani na slici 2.2 .

Za provedbu integriranog pristupa u praksu, trebamo uzeti u obzir da će u postupku provedbe razni dionici i njihova različita stajališta, mišljenja i pristupi biti skupa za jednim stolom, kako bi se postigao dogovor o dugoročnom pristupu održivom planiranju agregata. Ako zaista želimo sudjelovati, ljude treba pitati za mišljenje odmah na samom početku.

\section{Prednosti uključivanja dionika - iskustva projekta SNAP-SEE:}

$\checkmark$ Dionici koji predstavljaju vrlo različite organizacije okupili su se i počeli razgovarati, a u nekim slučajevima i po prvi puta.

$\checkmark$ Zapažen je značajan interes za sudjelovanjem u savjetovanju i angažiranost na događanjima, čak i kada se očekivala drukčija reakcija.

$\checkmark \quad$ Napredovala je suradnja između nadležnih tijela različitih sektora, npr., rudarstva, okoliša, voda, prostornog planiranja, transporta. itd., i na različitim razinama (nacionalnoj, regionalnoj, lokalnoj).

$\checkmark$ Podignuta je svijest o važnosti planiranja.

$\checkmark$ Prepoznata je potreba za izradom državne politike mineralnih sirovina.

$\checkmark \quad$ Identificirani su ključni problemi ili prepreke u planiranju (npr. procedure, nezakonita eksploatacija, nedostatak svijesti, itd.).

$\checkmark$ Izneseni su prijedlozi za moguća rješenja koje je prihvatila većina uključenih.

$\checkmark$ Promovirana je važnost recikliranja agregata.

$\checkmark$ Postavljen je ili unaprijeđen temelj za buduću suradnju.

Detaljnije informacije o postupku planiranja agregata mogu se pronaći u drugim dijelovima Alata za planiranje agregata:

- Vizija najbolje prakse za planiranje agregata u jugoistočnoj Europi;

- Kako napraviti Održivi plan agregata; i

- Podaci i analize kao potpora najboljim praksama u održivom planiranju agregata. 


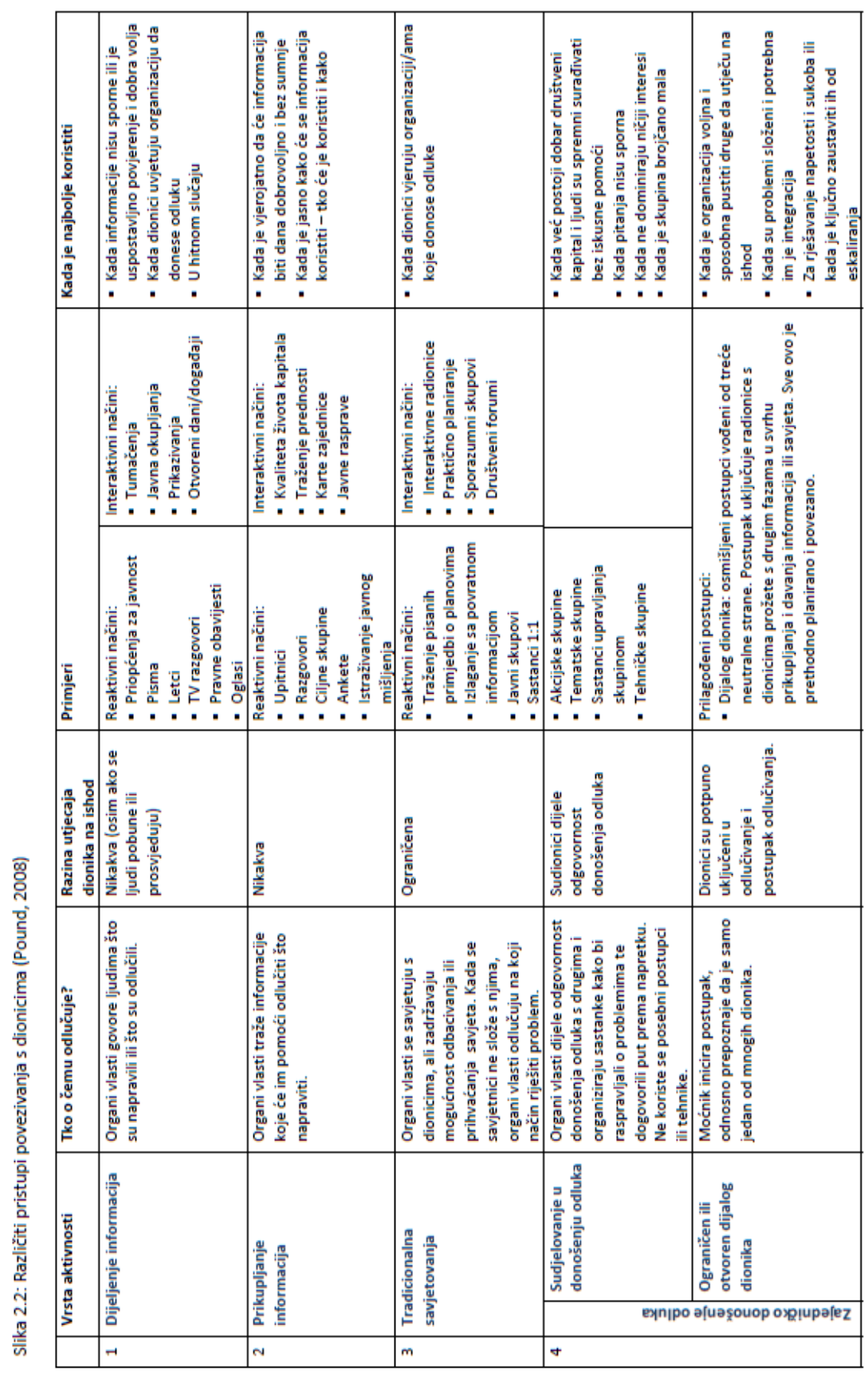




\section{Planiranje postupka sudjelovanja}

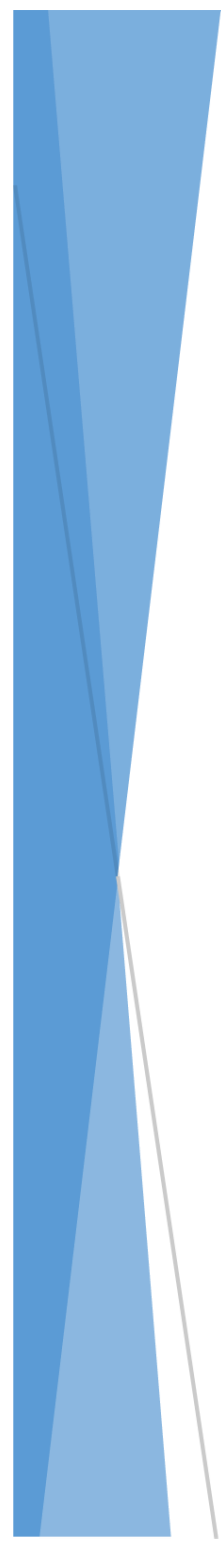

Kada odlučimo poboljšati politiku planiranja mineralnih sirovina/agregata na način da pošteno uključujemo dionike, trebamo pažljivo isplanirati $i$ odrediti postupak njihovog sudjelovanja, svrhu takvih postupaka, aktivnosti koje ćemo poduzeti i uloge uključenih ljudi.

Ovo poglavlje usredotočuje se na planiranje postupka sudjelovanja, dok sljedeća poglavlja objašnjavaju analizu dionika te savjete za planiranje i provedbu događanja $u$ tom postupku.

U projektu SNAP-SEE, krajnji cilj postupka savjetovanja bio je postići održivu opskrbu agregatima u zemljama ili regijama koje sudjeluju. Rezultati za svaku od uključenih zemalja/regija su analize trenutnog pristupa planiranju agregata $i$ nacionalne/regionalne smjernice o poboljšanju planiranja agregata za više sektora. Postignuti rezultat uključuje: bolje razumijevanje postupka planiranja agregata, dogovor o prihvatljivim rješenjima, povećani kapacitet u konceptima SARM i SSM te dobre prakse u drugim državama, povećanu osviještenost o održivim pristupima $i$ veće znanje o novim podacima i metodama. 


\subsection{Prije početka}

Suradnja pri uključivanju dionika u planiranje agregata znači prepoznati da si jedan među mnogim dionicima, a da se postignu najbolje odluke i drugi trebaju sudjelovati u raspravi. Kada se dobro provede, nastanu mnoge prednosti zbog uključivanja dionika, ali prije nego to učine, organizacije trebaju pažljivo razmisliti i osigurati da se radi iz pravih razloga. Razlog zbog kojeg treba pozvati ljude na sudjelovanje u planiranju treba biti taj što postoji stvarna mogućnost utjecanja na ishod. Sudjelovanje ne bi trebalo koristiti za potvrđivanje odluka koje su već donesene. Ako ljudi pomisle da se njihovo vrijeme koristi na loše odrađene/organizirane radionice ili da njihova prisutnost ne utječe na ishod, što je često slučaj, izgubit će povjerenje i poštovanje prema navedenim organizacijama.

Ako namjeravate uključivati dionike trebate znati zašto to radite. budu li dionici odvajali vrijeme za vaše sastanke ili postupke trebaju znati što se događa, zašto su uključeni, koji utjecaj mogu imati na ishod i kako se događanje odnosi na cjelokupni postupak donošenja odluka. Treba postojati istinsko zanimanje za slušanjem i razmatranjem tuđih mišljenja. Ključni ljudi trebaju razumjeti i podržati upotrebu ovog pristupa. Treba biti dovoljno vremena, stručnih ljudi i sredstava za vođenje postupka. (Pound, 2008).

Ključ uspješnog postupka leži u dobroj pripremi. Profesionalci kažu da je samo događanje poput vrha ledenjaka. Procjenjuje se da je čak $80 \%$ učinkovitosti dobrog postupka u pripremi. Cilj je pripremiti se dovoljno dobro kako bismo bili sigurni da sve što se dogodi na dan događanja protekne glatko i zaista učini razliku u tome kako ljudi surađuju (Pound, 2008).

\subsection{Koraci u planiranju postupka sudjelovanja}

Kada jednom odlučimo uključiti dionike u postupak sudjelovanja s ciljem održivog planiranja agregata, ključno je započeti s pažljivim planiranjem i pripremama. Planiranje postupka sudjelovanja sadrži nekoliko koraka, ovisno planiramo li dugogodišnji postupak ili jedno događanje. Ovo i sljedeća poglavlja objašnjavaju pet dijelova učinkovitog planiranja postupka sudjelovanja:

1. Razumijevanje situacije - svrha i rezultati

2. Postupak planiranja - plan djelovanja

3. Osmišljavanje događanja: planiranje, provedba i podsjetnik

4. Planiranje zadatka ili sastanka

5. Praktična organizacija. 
Dijelovi nisu u izravnom slijedu nego tvore postupak koji se ponavlja te u kojem svaki dio daje povratnu informaciju i pomaže oblikovati ostale dijelove. U svakom koraku postupka moramo imati na umu druge dijelove i, kada je potrebno, prilagoditi planirane aktivnosti, kako je prikazano na slici 3.1.

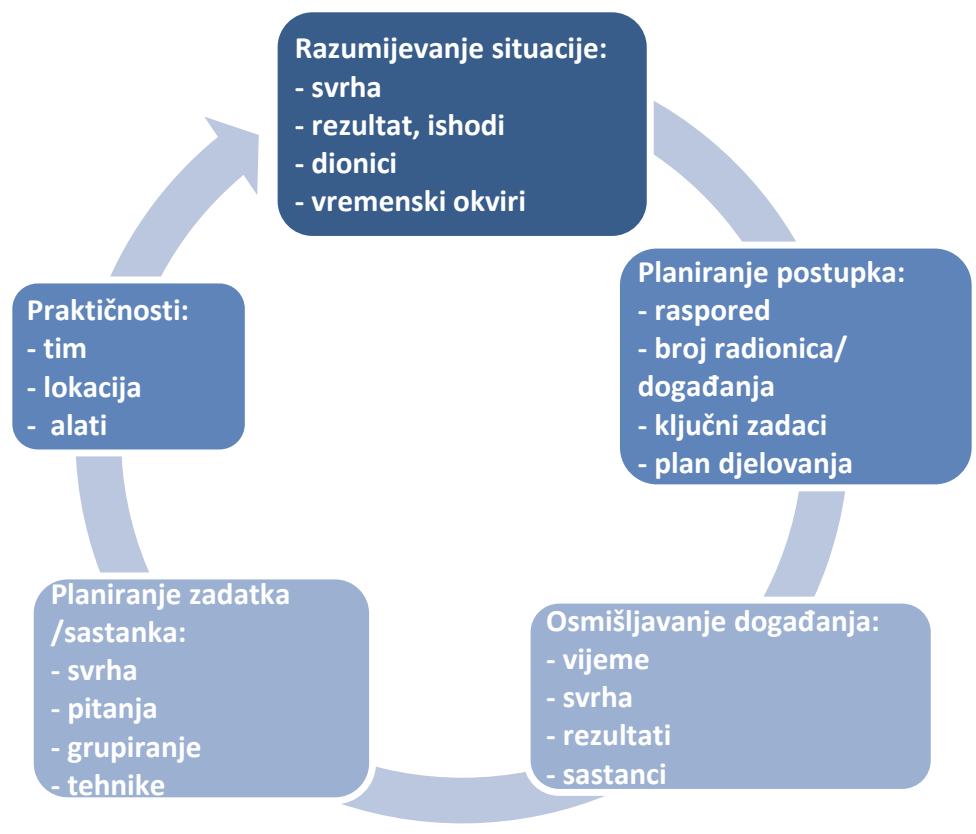

Slika3.1: Koraci učinkovitog planiranja postupka sudjelovanja (Pound, 2008)

Ključni cilj postupka planiranja je omogućiti najučinkovitiji postupak: koji odgovara svrsi, koji je prilagođen potrebama sudionika, poželjnim ishodima i dostupnim resursima.

\subsection{Surha i koraci u postupku sudjelovanja}

Točke i pitanja u tablici u nastavku teksta pomažu u pojašnjavanju situacije i poželjnog ishoda postupka te bi trebali omogućiti dobro razumijevanje prije početka samog postupka. Pitanja nas vode kroz definiranje svrhe cijelog postupka sudjelovanja - što želimo postići u određenim okolnostima.

Određivanje svrhe postupka - glavna pitanja (Pound, 2008)

Svrha $\quad$ Što je osnovna svrha ovog postupka/događanja?

Što je realno i moguće postići s raspoloživim resursima, osobljem, 


\begin{tabular}{|l|l|}
\hline \multirow{2}{*}{ Rezultati } & $\begin{array}{l}\text { vremenom i budžetom? } \\
\text { Što inicijatori žele dobiti do kraja postupka, a nemaju sada? } \\
\text { Kako će znati je li postupak bio uspješan? Kakav će biti osjećaj, kako će } \\
\text { izgledati? }\end{array}$ \\
\hline Ishodi & $\begin{array}{l}\text { Što su konkretni proizvodi? } \\
\text { Primjeri: izvješće stručnjaka, plan djelovanja, lista prioriteta }\end{array}$ \\
& $\begin{array}{l}\text { Što ljudi žele promijeniti kao rezultat ovog postupka? } \\
\text { Relacijski ishodi uključuju: bolje odnose, bolje razumijevanje, više otkupa i } \\
\text { vlasništva, aktivnu podršku, jače timove, više povjerenja, povećanu } \\
\text { suradnju, smanjenje napetosti, bolje odluke } \\
\text { Sadržajni ishodi mogu biti: bolje upravljanje okolišem, bolje održiva } \\
\text { upotreba/razvoj, dogovor o najboljoj praksi }\end{array}$ \\
\hline Ljudi & $\begin{array}{l}\text { Kome je namijenjen ovaj postupak? } \\
\text { Tko bi trebao biti uključen i u kojoj mjeri? } \\
\text { Tko su dionici (također pogledati poglavlje 4)? }\end{array}$ \\
\hline Sadržaj & $\begin{array}{l}\text { Što je težište rasprave? } \\
\text { Što su problemi, koje su teme i brige? } \\
\text { Što treba riješiti? }\end{array}$ \\
\hline $\begin{array}{l}\text { Poznati rokovi - zakonski rokovi, sastanci, tiskanje, financiranje itd. } \\
\text { Ključna događanja važna za projekt, slična događanja, očekivana promjena } \\
\text { osoblja ili organizacije } \\
\text { Javna događanja: javni i vjerski praznici, izbori, međunarodna sportska } \\
\text { događanja, lokalna događanja } \\
\text { Ograničenja: radna sezona za dionike, praznici, kraj fiskalne godine, } \\
\text { dostupnost osoblja u organizaciji, voditelj i tim }\end{array}$ \\
\hline
\end{tabular}

Jednom kada promislimo o svemu navedenom trebali bi mnogo bolje razumjeti što je točno postupak i početi detaljnije planirati njegove korake. Proces sudjelovanja može imati različite ciljeve koji rezultiraju i različitim vrstama aktivnosti i zadataka koji se koriste između i za vrijeme događanja. Kako bi postigli određenu svrhu trebamo odrediti manje među-ciljeve koji će se postići manjim zadacima samog postupka, broj događanja koji su potrebni za postizanje cjelokupne svrhe te privremene ciljeve. $U$ većini slučajeva, postupak sudjelovanja prati sljedeće korake:

$\checkmark$ Analiziranje situacije, problema, pozadinskih razloga (tj., koje je trenutno stanje planiranja, tko sudjeluje, tko bi još trebao sudjelovati, što funkcionira, a što bi trebalo popraviti, itd.);

$\checkmark$ Određivanje zajedničke vizije - gdje želimo biti u budućnosti;

$\checkmark$ Prepoznavanje rješenja;

$\checkmark$ Analiziranje izvedivosti rješenja i njihovo prihvaćanje od strane dionika; te

$\checkmark$ Odabir rješenja i definiranje planiranja djelovanja (tko će što odraditi i do kada). 
Ključni dio razgovora s dionicima je oblikovanje i prilagođavanje situaciji svakog događanja ili postupka. Na temelju gore navedene analize možemo odrediti: (a) cjelokupni cilj postupka, (b) broj događanja (radionice, manji sastanci itd.) i (c) uvrštavanje ključnih faza u raspored postupka.

Kod savjetovanja za najbolje prakse u planiranju agregata, postoje tri ključna cilja postupka sudjelovanja:

1. Jačanje kapaciteta (ključnih) dionika u održivom gospodarenju kamenim agregatima (SARM) i u osiguranju održive mješovite opskrbe (SSM);

2. Savjetovanja s dionicima o postojećoj situaciji: analize trenutnog pristupa planiranju, zakonodavstva, propisa, prepreka, praznina, uskih grla itd.; i

3. Savjetovanja s dionicima o mogućim rješenjima: predlaganje mogućih rješenja kako bi se prevladale prepreke $\mathrm{i}$ odredili koraci, raspored $\mathrm{i}$ odgovornosti za njihov uspjeh.

Opći postupak za potporu najboljih praksi u održivom planiranju agregata je sljedeći:

\begin{tabular}{|c|c|}
\hline \multicolumn{2}{|c|}{ Cjelokupni postupak planiranja za savjetovanje s dionicima u projektu SNAP-SEE: } \\
\hline $\begin{array}{l}\text { Postavljanje općeg } \\
\text { cilja }\end{array}$ & Postizanje održive opskrbe agregatima u mojoj zemlji/regiji \\
\hline $\begin{array}{l}\text { Određivanje svrhe } \\
\text { postupka } \\
\text { sudjelovanja }\end{array}$ & $\begin{array}{l}\text { Analizirati postojeće stanje u planiranju agregata i tražiti rješenja kako } \\
\text { bi se svladale postojeće prepreke u suradnji s predstavnicima različitih } \\
\text { ciljnih skupina iz svih obuhvaćenih sektora } \\
\text { Napraviti smjernice za razvoj politike agregata ili je učiniti održivom, } \\
\text { povezujući opskrbu primarnih i sekundarnih agregata }\end{array}$ \\
\hline $\begin{array}{l}\text { Određivanje } \\
\text { ključnih dionika }\end{array}$ & $\begin{array}{l}\text { Vidi poglavlje 4: Predstavnici javnih vlasti, stručne organizacije, } \\
\text { industrija, lokalne zajednice, nevladine organizacije i mediji }\end{array}$ \\
\hline $\begin{array}{l}\text { Rezultati } \\
\text { savjetovanja }\end{array}$ & $\begin{array}{l}\text { Analize više sektora trenutnog pristupa planiranju agregata; } \\
\text { državne/regionalne smjernice o poboljšanju planiranja agregata }\end{array}$ \\
\hline Ishodi savjetovanja & $\begin{array}{l}\text { Bolje razumijevanje postupka planiranja agregata i trenutnih } \\
\text { ograničenja, dogovor o rješenjima, povećanje kapaciteta u konceptima } \\
\text { SARM i SSM, povećanje mogućnosti dobrih praksi u drugim zemljama, } \\
\text { povećana osviještenost o pristupima održivosti, povećano znanje o } \\
\text { ažuriranju podataka i metodama }\end{array}$ \\
\hline $\begin{array}{l}\text { Određivanje broja } \\
\text { događanja }\end{array}$ & $\begin{array}{l}\text { Preporučuje se provesti barem dva događanja o savjetovanju (radionice } \\
\text { za jačanje mogućnosti, prikupljanje informacija, određivanje i } \\
\text { analiziranje rješenja), gdje će prisustvovati predstavnici svih uključenih } \\
\text { sektora; između se trebaju planirati manji sastanci i sastanci osnovne } \\
\text { skupine }\end{array}$ \\
\hline Vrijeme & $\begin{array}{l}\text { Općenito, potrebno je približno godinu dana za provedbu ovakvog } \\
\text { postupka }\end{array}$ \\
\hline
\end{tabular}


Predložak 1 može se koristiti u planiranju svrhe postupka sudjelovanja.

Predložak 1: Svrha postupka sudjelovanja u mojoj zemlji/regiji

\begin{tabular}{|c|c|}
\hline Pitanja & Odgovori za postupak u mojoj zemlji/regiji \\
\hline $\begin{array}{l}\text { Što želimo postići na kraju postupka? } \\
\text { Koji su očekivani rezultati? }\end{array}$ & \\
\hline $\begin{array}{l}\text { Koje informacije želimo podijeliti ili } \\
\text { prikupiti? } \\
\text { Što bi bile osnovne poruke? } \\
\text { Što će sudionici dobiti od postupka i } \\
\text { događanja? }\end{array}$ & \\
\hline $\begin{array}{l}\text { Koji su opipljivi učinci na kraju } \\
\text { postupka? }\end{array}$ & \\
\hline Kako će se koristiti učinci i rezultati? & \\
\hline Koliko događanja planiramo održati? & \\
\hline
\end{tabular}

\section{Svrha postupka sudjelovanja - primjeri savjetovanja na projektu SNAP-SEE:}

$\checkmark \quad$ U postupak planiranja agregata treba uključiti najvažnije dionike kao što su vlada, lokalna nadležna tijela, privatni sektor, građansko društvo i zajednice.

$\checkmark$ Postići dogovor oko plana eksploatacije agregata koji će osigurati održivi razvoj i povećati mogućnosti recikliranja.

$\checkmark \quad$ Uključiti sekundarne agregate u planiranje kao mogući izvor za razvoj infrastrukture na ekološki prihvatljiv način.

$\checkmark$ Biti u skladu sa strateškom politikom države i EU.

$\checkmark$ Postići sinergiju između različitih planova i strategija u vezi agregata.

Nakon što smo odredili potrebne korake, trebamo ih razmotriti unutar raspoloživog vremena, kako bismo imali dovoljno vremena posvetiti se svakom koraku. Sljedeće poglavlje opisuje kako odrediti vremenski okvir za provedbu postupka sudjelovanja. 


\subsection{Vremenski period za određivanje postupka sudjelovanja}

Nakon što smo odlučili o sveukupnom cilju našeg postupka i posebnim ciljevima određenih faza postupka, vrlo je korisno pripremiti vremenski okvir s vremenskim fazama:

$\checkmark$ Broj i vrsta događanja koji će biti organizirani;

$\checkmark$ Privremeni manji sastanci;

$\checkmark$ Aktivnosti organizacijske skupine prije i poslije događanja; te

$\checkmark \quad$ Najprihvatljivije vrijeme u skladu s okolnostima (blagdani, itd.).

Tablica vremenskog rasporeda sadrži vremenske faze u gornjem redu (dostupni mjeseci od početka planiranja do zaključivanja postupka) i različite vrste aktivnosti/ ograničenja na lijevoj strani. U tablicu unosimo:

$\checkmark$ Projekt/druge važne ključne točke koje utječu na naš postupak;

$\checkmark$ Ograničenja kao što su praznici, godišnji odmori, školski praznici, drugi važni događaji i sl.;

$\checkmark$ Datumi pogodni za isplanirana događanja u postupku (radionice s dionicima, manji sastanci itd.);

$\checkmark$ Aktivnosti tima za koordinaciju; te

$\checkmark$ Aktivnosti s dionicima.

Primjer tablice na temelju plana projekta SNAP-SEE prikazan je u Predlošku 2. Detaljne upute za planiranje koraka postupka i pojedinog događanja opisane su u sljedećim poglavljima, a iduće poglavlje usredotočeno je na definiranje dionika. 
Predložak 2: Raspored postupka sudjelovanja u mojoj zemlji/regiji

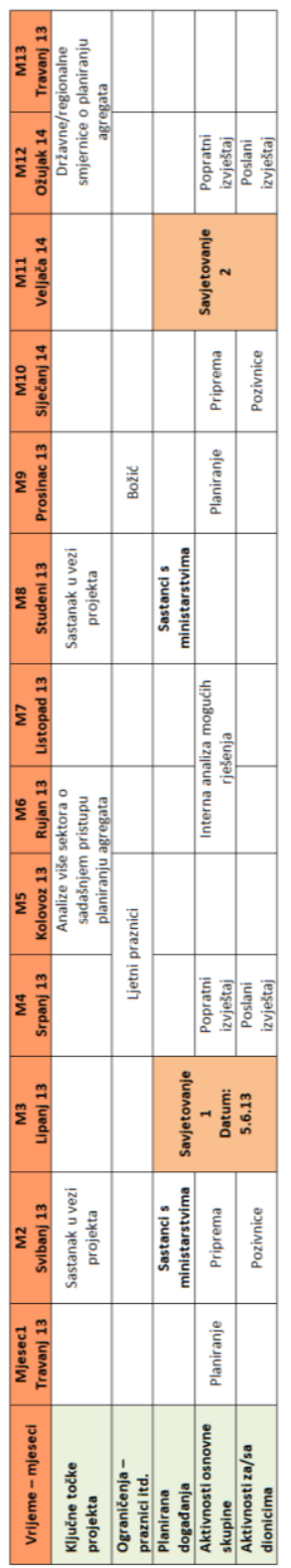




\section{Tko su dionici i kako ih uključiti}

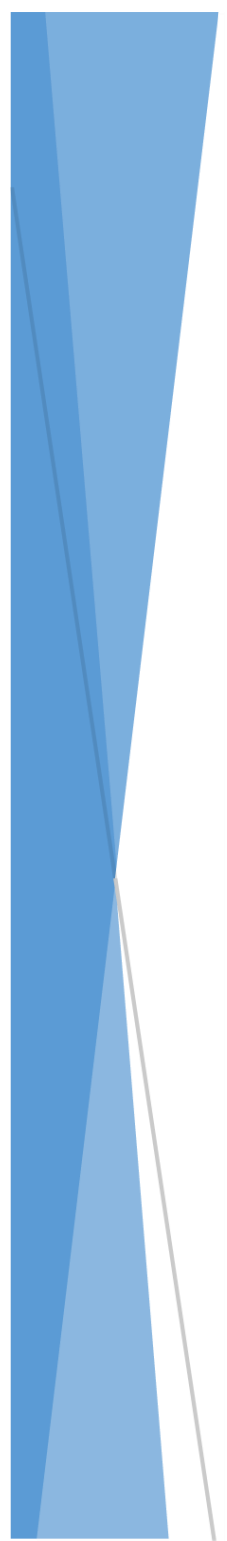

Dionici mogu biti bilo koja osoba, skupina ili organizacija na koju će vjerojatno utjecati ili ju zanimati-donesene odluke. To obuhvaća sve organizacije ili osobe koje su zadužene za planiranje agregata, direktno pogođene postupcima planiranja, koje su uključene ili na njih utječe eksploatacija te aktivnosti prije ili poslije eksploatacije.

Kada razmislimo o postupku uključivanja dionika, prvi korak je prepoznavanje različitih interesnih skupina, odnosno dionika. Od ključne važnosti je drugi korak koji analizira uloge i interese različitih skupina i na osnovi toga definira ono što želimo postići te koji je najprikladniji način uključivanja tih skupina. Često se smatra da svi dionici moraju biti uključeni na isti način tijekom postupka; međutim, to nije slučaj. Jedan od koraka kod planiranja uključivanja dionika je određivanje najprikladnijih aktivnosti za različite skupine, od davanja $i$ prikupljanja informacija do događanja namijenjenim savjetovanju. 


\subsection{Prepoznavanje dionika u planiranju agregata}

Ispod su navedeni dionici uključeni u planiranje agregata prema sektorima i prema različitim vrstama organizacija. Trebamo imati na umu da popis dionika (važnih organizacija, skupina i pojedinaca) nikad nije gotov i da analize nikad nisu završene cijelo vrijeme će biti ponovno razmatran $i$, po potrebi, izmijenjen tijekom razvoja postupka.

\section{Skupine dionika uključenih u planiranje agregata prema sektorima:}

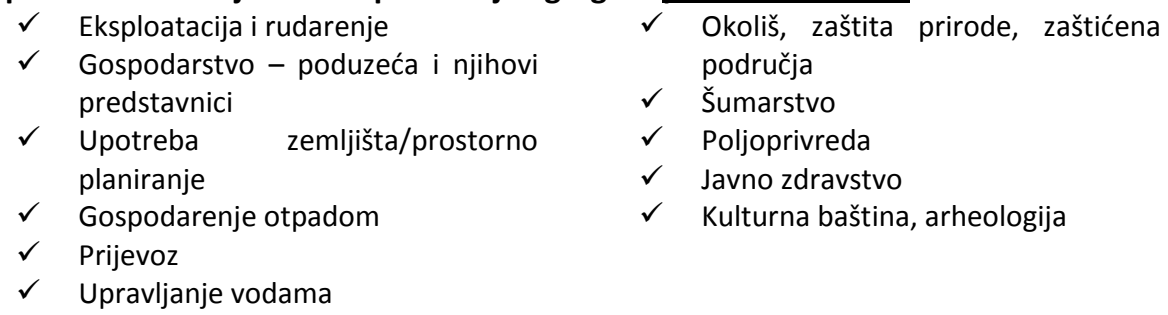

Tablica 4.1: Dionici prema vrstama organizacije

\begin{tabular}{|c|c|}
\hline 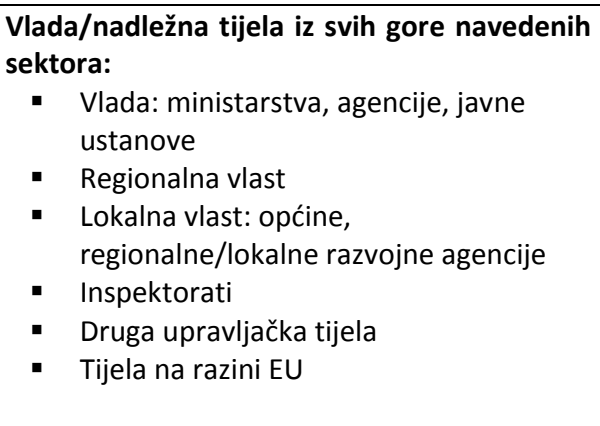 & $\begin{array}{l}\text { Industrija agregata: } \\
\text { - } \text { Vlasnici kamenoloma } \\
\text { - } \text { Rukovoditelji kamenoloma } \\
\text { - } \text { Radnicici i radnička udruženja } \\
\text { - } \text { Udruge - regionalne, državne i } \\
\text { - } \text { međunarodne } \\
\text { - Gospodarske komore } \\
\text { - } \quad \text { Prađevinska industrija } \\
\text { - } \quad \text { Sindikači }\end{array}$ \\
\hline $\begin{array}{l}\text { Stručnjaci: } \\
\text { - } \quad \text { Geološke službe, instituti za istraživanje } \\
\text { Instituti iz drugih gore navedenih } \\
\text { zektora (prostorno planiranje, okoliš, } \\
\text { zaštita prirode, gospodarenje otpadom, } \\
\text { prijevoz, upravljanje vodama, } \\
\text { - Soljoprivreda, šumarstvo itd.) } \\
\text { - Sveučilišta i druge obrazovne } \\
\text { - Stručnjaci za rudarstvo, geolozi itd. } \\
\text { - Međunarodni instituti }\end{array}$ & $\begin{array}{l}\text { Zajednice i nevladine organizacije, } \\
\text { dobrovoljni sektor: } \\
\text { - Vlasnici zemljišta } \\
\text { - Lokalno stanovništvo, poljoprivrednici } \\
\text { - Nevladine organizacije u području } \\
\text { zaštite okoliša, ekolozi, zaštita ptica itd. } \\
\text { - Građanske udruge }\end{array}$ \\
\hline \multicolumn{2}{|c|}{ Mediji, šira javnost } \\
\hline
\end{tabular}


Kada razmišljamo o dionicima i kako prepoznati one bitne za događanja, ova pitanja će vas usmjeravati:

$\checkmark$ Koje organizacije i pojedinci su zaduženi ili imaju interes u planiranju agregata?

$\checkmark \quad$ Tko su ljudi koji ih predstavljaju?

$\checkmark$ Koje informacije/znanja su im potrebna?

$\checkmark \quad$ Na koga će rezultati događanja/projekta direktno utjecati?

$\checkmark \quad$ Tko je izravno odgovoran za donošenje odluka o razmatranim pitanjima?

$\checkmark \quad$ Tko je utjecajan u ovoj temi/regiji/organizaciji?

$\checkmark \quad$ Tko je bio uključen u ovaj problem u prošlosti?

$\checkmark \quad$ Tko nije bio uključen, ali je trebao biti?

$\checkmark$ Tko su ključni "pokretači” koji mogu dodatno pomoći u daljnjoj promociji rezultata i odluka?

$\checkmark$ Tko su protivnici i „blokatori“ vaših ideja, inicijative koje je općenito bolje uključiti u postupak nego da negativno govore o vašim naporima izvan procesa/projekta dajući mu time negativan publicitet?

Moramo imati na umu moć različitih skupina ili pojedinaca koji utječu na odluke i razinu njihovog interesa dotične teme. Ove dvije kategorije tvore osnovu za podjelu dionika u različite skupine kojima će se pristupiti na različite načine tijekom postupka, što je objašnjeno u sljedećem poglavlju.

\subsection{Grupiranje dionika prema ulogama}

Dionici s većim utjecajem na donošenje odluka koje djeluju na planiranje agregata (npr. nadležna ministarstva) trebaju biti uključeni u postupak aktivnije od drugih skupina s navedenog popisa. To ne znači da njihovo mišljenje neće imati utjecaj ili da neće biti razmotreno, ali $s$ druge strane znači prilagođavanje postupka našim mogućnostima za provedbu i željeni ishod.

Na ovaj način, prema interesu, ulozi i razini uključenosti dionika, možemo ih podijeliti na četiri različite skupine $s$ različitim ulogama.

\begin{tabular}{|l|l|}
\hline Skupina & Uloga \\
\hline Tim za \\
koordinaciju & $\begin{array}{l}\text { Predstavnici organizacija za koordinaciju, tj. partneri projekta i promatrači } \\
\text { iz svake zemlje/regije: surađuju u svim aktivnostima projekta, definiraju, } \\
\text { planiraju i provode postupak sudjelovanja, organiziraju događanja, pišu } \\
\text { tekstove i izvješća. Vode i primjenjuju cijeli postupak te pripremaju } \\
\text { dokumentaciju. }\end{array}$ \\
\hline Radna skupina & $\begin{array}{l}\text { Predstavnici ključnih organizacija odgovornih za planiranje primarnih i } \\
\text { sekundarnih agregata: pružaju informacije za pripremu analiza i izvješća te }\end{array}$ \\
\hline
\end{tabular}




\begin{tabular}{|l|l|}
\hline & $\begin{array}{l}\text { sudjeluju na događanjima s dionicima. Imaju aktivnu ulogu tijekom cijelog } \\
\text { postupka. Osim događanja, mogu sudjelovati i na manjim sastancima kako } \\
\text { bi osigurali pravilno planiranje, provedbu i praćenje postupka sudjelovanja } \\
\text { te osigurali najnovije podatke za izvješća. Ispunjavaju dokumentaciju i } \\
\text { sudjeluju na događanjima s dionicima. }\end{array}$ \\
\hline $\begin{array}{l}\text { Predstavnici } \\
\text { ključnih skupina } \\
\text { dionika }\end{array}$ & $\begin{array}{l}\text { Predstavnici različitih skupina dionika (sektori i vrste organizacija) } \\
\text { navedenih iznad, koji su također ključni za donošenje odluka i kreatori } \\
\text { mišljenja. Na njih utječu aktivnosti planiranja agregata i njihov glas se mora } \\
\text { čuti. Ključna uloga im je dati svoja mišljenja i informacije na događanjima } \\
\text { savjetovanja. Ako je potrebno, mogu se savjetovati i međusobno. Sudjeluju } \\
\text { na događanjima. }\end{array}$ \\
\hline $\begin{array}{l}\text { Šira javnost i } \\
\text { mediji }\end{array}$ & $\begin{array}{l}\text { Predstavnici medija i šire javnosti, zainteresirani za temu: opće promotivne } \\
\text { aktivnosti usmjerene su ka njima, kao što su web stranice projekta, članci, } \\
\text { letci i brošure. Informirani su o projektu. }\end{array}$ \\
\hline
\end{tabular}

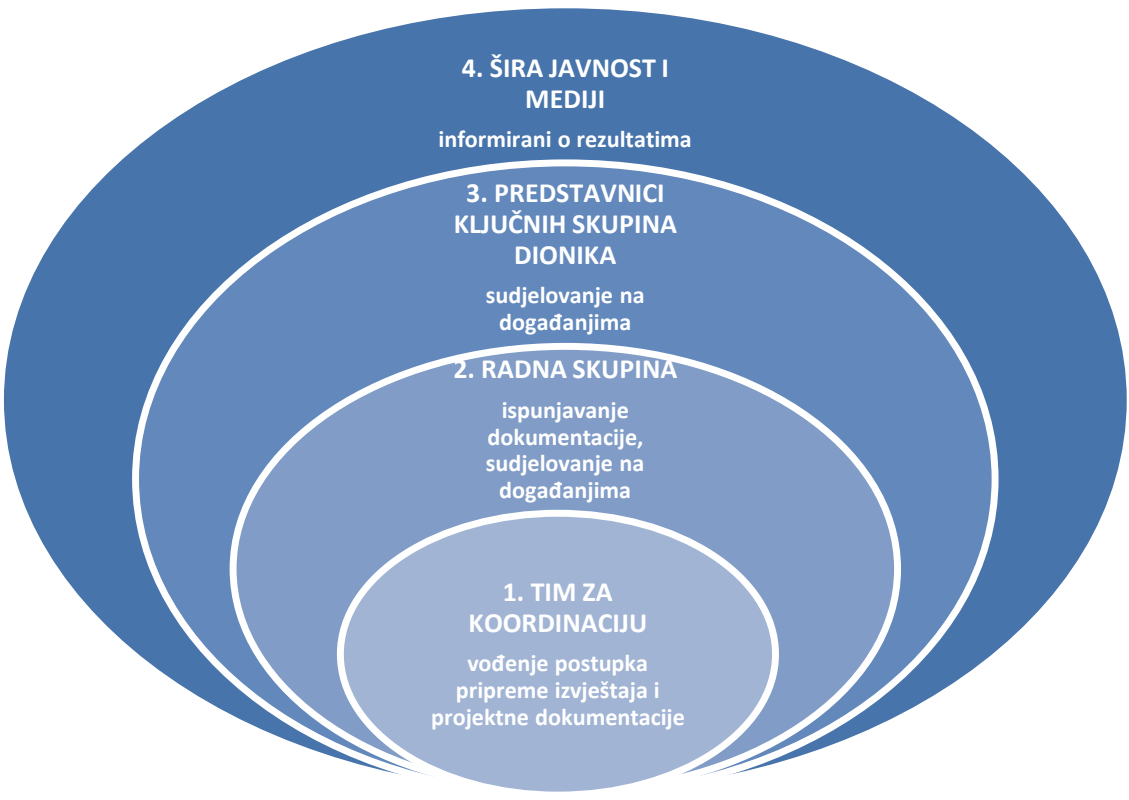

Slika 4.1: Grupiranje dionika u četiri skupine na osnovi razine njihove uključenosti

Svaka od četiri skupine ima drukčiju ulogu i zadatak. Zadaci tima za koordinaciju i radne skupine detaljnije su objašnjeni u sljedećim poglavljima. 
Prilikom prepoznavanja i analiziranja predstavnika dionika od ključne je važnosti prepoznati ne samo uključene organizacije, već i osobe koje su zadužene ili na koje utječe tema kojom se bavimo. Predložak 3 u nastavku uvršten je na popis ključnih dionika, gdje trebamo prepoznati i osobe koje poznaju područje ili imaju određenu odgovornost i mišljenje koje treba uzeti u obzir. Na temelju ovog popisa dionika mora se pripremiti lista kontakata $s$ adresama, elektroničkom poštom i telefonskim brojevima svih bitnih osoba, kako bi se mogla koristiti u komunikaciji s dionicima:
$\checkmark$ Prilikom prikupljanja važnih informacija prije ili između događanja;
$\checkmark \quad$ Kako bismo im poslali pozivnice za događanja,
$\checkmark$ Za slanje izvještaja o provedenim događanjima;
$\checkmark$ Za informiranje o sljedećim koracima u postupku; i
$\checkmark \quad$ Kako bismo ih kontaktirali o dodatnim potrebnim informacijama.

\section{Iskustvo s uključivanjem različitih dionika u projektu SNAP-SEE:}

$\checkmark \quad$ Interesi različitih ciljnih skupina uvelike variraju. Njihova mišljenja dosta se razlikuju i mogu biti međusobno suprotna. Stoga, trebate pažljivo razmotriti kako surađivati sa svima i kako izbjeći eskalaciju sukoba. Neki savjeti o tehnikama moderiranja predstavljeni su u poglavlju 6.

$\checkmark$ Predstavnici različitih skupina pokazali su interes za sudjelovanje u savjetovanjima.

$\checkmark \quad$ Ključno je odrediti ne samo nadležnu organizaciju već i pravu osobu koja se bavi temom savjetovanja.

$\checkmark$ Veliki je izazov motivirati predstavnike nadležnih tijela. Nužno je obavijestiti ih o prednostima i očekivanim ishodima savjetovanja.

$\checkmark \quad$ Industrija je jako motivirana za suradnju pa moramo pripaziti da je jednako zastupljena. Najviše ih zanima da nadležna tijela osiguraju stabilne i pravedne uvjete rada za njihovo poslovanje.

$\checkmark$ Stručne organizacije i stručnjaci iz različitih područja pružit će važne uvide u različite teme.

$\checkmark$ Predstavnici sektora za zaštitu okoliša, nevladine organizacije i zajednice također su zainteresirane da budu uključene u dijalog od početka kako bi se i njihova mišljenja uzela u obzir. Iskustvo pokazuje da nisu „a priori“ protiv već spomenutih aktivnosti (eksploatacije), ali prečesto su ostavljeni za posljednju fazu postupka. 
Predložak 3: Popis organizacija dionika i kontakt osoba

\begin{tabular}{|c|c|c|c|c|c|c|}
\hline $\begin{array}{l}\text { Vrsta } \\
\text { organizacije }\end{array}$ & Organizacija & $\begin{array}{l}\text { Kojoj } \\
\text { skupini } \\
\text { pripada } \\
1-4 ?\end{array}$ & $\begin{array}{l}\text { Kontakt } \\
\text { osoba }\end{array}$ & $\begin{array}{l}\text { E-mail } \\
\text { adresa }\end{array}$ & $\begin{array}{l}\text { Broj } \\
\text { telefona }\end{array}$ & $\begin{array}{l}\text { Tko ih } \\
\text { kontaktira? }\end{array}$ \\
\hline $\begin{array}{l}\text { Nadležno } \\
\text { ministarstvo za } \\
\text { rudarstvo }\end{array}$ & & & & & & \\
\hline $\begin{array}{l}\text { Nadležno } \\
\text { ministarstvo za } \\
\text { zaštitu okoliša }\end{array}$ & & & & & & \\
\hline $\begin{array}{l}\text { Druga važna } \\
\text { ministarstva ili } \\
\text { agencije }\end{array}$ & & & & & & \\
\hline Regionalne vlasti & & & & & & \\
\hline $\begin{array}{l}\text { Tijelo nadležno za } \\
\text { gospodarenje } \\
\text { otpadom }\end{array}$ & & & & & & \\
\hline $\begin{array}{l}\text { Tijelo nadležno za } \\
\text { prijevoz }\end{array}$ & & & & & & \\
\hline $\begin{array}{l}\text { Tijelo nadležno za } \\
\text { upravljanje } \\
\text { vodama }\end{array}$ & & & & & & \\
\hline $\begin{array}{l}\text { Tijelo nadležno } \\
\text { za... }\end{array}$ & & & & & & \\
\hline $\begin{array}{l}\text { Instituti, } \\
\text { organizacije za } \\
\text { istraživanja, } \\
\text { sveučilišta }\end{array}$ & & & & & & \\
\hline $\begin{array}{l}\text { Predstavnici } \\
\text { lokalnih } \\
\text { nadležnih tijela }\end{array}$ & & & & & & \\
\hline $\begin{array}{l}\text { Nevladine } \\
\text { organizacije }\end{array}$ & & & & & & \\
\hline $\begin{array}{l}\text { Predstavnici } \\
\text { lokalnih zajednica }\end{array}$ & & & & & & \\
\hline$\ldots$ & & & & & & \\
\hline
\end{tabular}




\section{Planiranje događanja s dionicima}

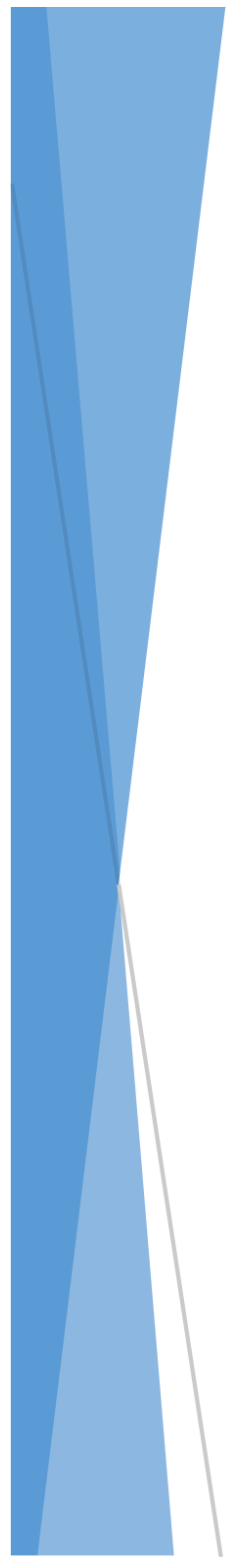

Nakon što smo odlučili koji su ključni aspekti postupka sudjelovanja, tj. svrhu, dionike i broj događanja te njihovo vrijeme održavanja, možemo početi planirati detalje prvog događanja. Prethodna poglavlja bila su usmjerena na ključne parametre koji određuju cjelokupni postupak, dok sljedeća poglavlja sadrže praktične savjete za provedbu događanja, tj. radionica, seminara ili sastanaka $s$ predstavnicima dionika. Ovo poglavlje predstavlja pojedinosti za organiziranje događanja: vremenski rok, tim, točno vrijeme i mjesto, dnevni red i pozivnice.

U SNAP-SEE projektu, održano je 20 savjetovanja u 10 zemalja, s preko 800 sudionika iz 90 organizacija, predstavljajući sve ciljane skupine. Ovo poglavlje rezimira iskustvo organiziranja takvog događanja, a detalji su predstavljeni u publikaciji završnog projekta (dostupno na http://snapsee.eu). Bitno je početi planirati dovoljno rano, dobro se pripremiti, rasporediti zadatke između članova tima i osigurati nastavak nakon događanja. Sve ovo će doprinijeti uspješnom ostvarenju cilja događanja, tj. pronalasku zajedničkih rješenja za bolje planiranje agregata. 


\subsection{Vrijeme potrebno za organiziranje događanja}

Ključne aktivnosti za organiziranje događanja sažete su na slici 5.1. Složene su prema vremenskom slijedu: što treba obaviti prije događanja, za vrijeme događanja i nakon događanja.

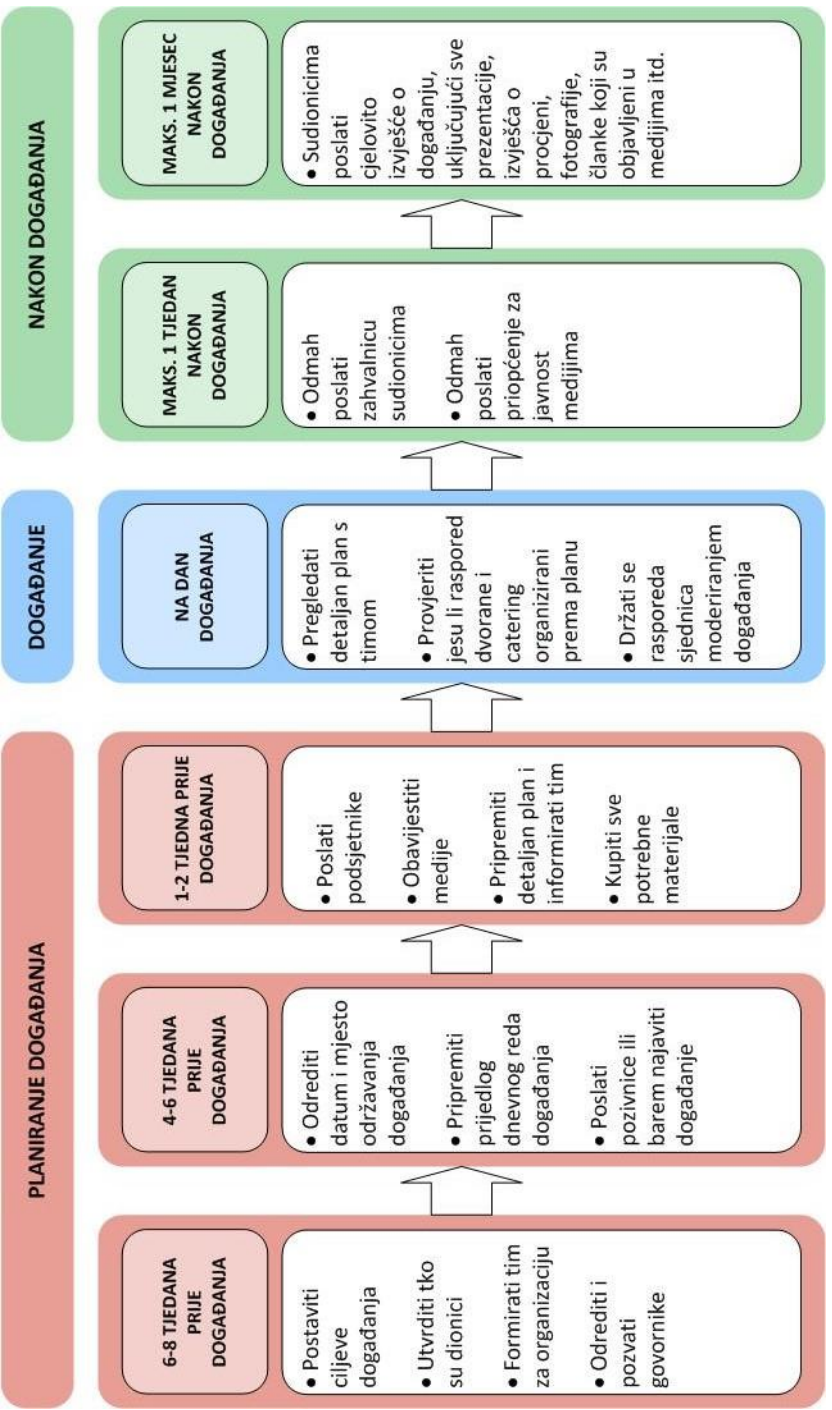

Slika 5.1: Vremenski rok za organiziranje događanja s dionicima (Softić i dr., 2011) 


\subsection{Tko je u mome timu}

Organiziranje sastanka ili radionice s dionicima sadrži brojne aktivnosti. Stoga se preporučuje oformiti tim za koordinaciju i podijeliti zadatke između nekoliko članova tima. Prije svega, treba imenovati osobu koja će biti zadužena za događanje. Čak i ako prepustimo organiziranje događanja vanjskim stručnjacima, uvijek treba imenovati glavnog organizatora "iz kuće" kako bi nadgledao njihov rad i bio u kontaktu s njima zbog eventualnih problema. Kada razmišljamo o raspodijeli zadataka članovima tima, provedbi i onog što slijedi nakon toga, glavni zadaci koje treba isplanirati u pripremanju događanja navedeni su ispod.

\begin{tabular}{|c|c|}
\hline Faza & Glavni zadaci \\
\hline $\begin{array}{l}\text { Pripremanje } \\
\text { događanja }\end{array}$ & $\begin{array}{l}\text { - Pripremanje sadržaja i detaljnog programa događanja } \\
\text { - Pripremanje pozivnica, drugih informativnih materijala } \\
\text { - Pozivanje govornika, raspored prezentacija } \\
\text { - } \text { Rezerviranje mjesta održavanja, organiziranje domjenka } \\
\text { - Surađivanje s medijima (slanje priopćenja za javnost, razgovori s } \\
\text { novinarima, obavijesti o događanjima na različitim web stranicama) } \\
\text { - Nabava potrebnog uredskog materijala (papirnate blokove, olovke, } \\
\text { oznake s imenom ili naljepnice itd.) } \\
\text { Dogovaranje informatičke opreme za događanje (prijenosno računalo, } \\
\text { projektori, mikrofoni itd.) } \\
\text { Planiranje proračuna i dogovori o plaćanju } \\
\text { računovodstvom/pravnom službom }\end{array}$ \\
\hline $\begin{array}{l}\text { Za vrijeme } \\
\text { događanja }\end{array}$ & $\begin{array}{l}\text { - Imenovati osobu koja će biti zadužena za koordinaciju na mjestu } \\
\text { - } \quad \text { događanja i koja će donositi sve odluke o bilo kakvim promjenama } \\
\text { - } \quad \text { Prijem govornika, preuzimanje njihovih prezentacija, postavljanje } \\
\text { - } \quad \text { Izgled prostontacija na prijenosno računalo /projektor } \\
\text { - } \quad \text { Priprema papira i drugih materijala } \\
\text { - } \quad \text { Organiziranje domjenka } \\
\text { - } \quad \text { Postavljanje plakata } \\
\text { - } \quad \text { Vođenje događanja } \\
\text { - Zapisivanje diskusije } \\
\text { - Čišćenje mjesta nakon događanja } \\
\text { - } \quad \text { Briga oko plaćanja, računi }\end{array}$ \\
\hline $\begin{array}{l}\text { Nakon } \\
\text { događanja }\end{array}$ & $\begin{array}{l}\text { - Izrada izvješća o događanju i prosljeđivanje sudionicima i drugim } \\
\text { - Slanje zahvalnica gostujućim govornicima } \\
\text { - } \quad \text { Pisanje i slanje priopćenja za javnost medijima } \\
\text { - } \quad \text { Utvrditi buduće zadatke vezane uz samo događanje ili projekt (npr. } \\
\text { informacije za izvješća o projektu) }\end{array}$ \\
\hline
\end{tabular}


U podjeli uloga i postavljanja rokova može se koristiti Predložak 4 za definiranje odgovornosti članova uključenih u tim.

Predložak 4: Odgovornosti tima za koordinaciju

\section{TIM ZA KOORDINACIJU}

Osoba zadužena za organizaciju:

Drugi članovi tima i njihovi zadaci:

\begin{tabular}{|l|l|l|}
\hline Osoba & Zadaci & Rokovi \\
\hline$\ldots$ & $\ldots$ & $\ldots$ \\
\hline & & \\
\hline
\end{tabular}

\subsection{Odabrati pravo vrijeme i mjesto za događanje}

Kako bi se nastavilo s planiranjem i pripremanjem pozivnica, u sljedećem koraku treba se odlučiti o vremenu i mjestu događanja.

Trajanje događanja: nema pravila koliko bi događanje trebalo trajati. Najvažnije je da znate što želite reći sudionicima i da za to isplanirate dovoljno vremena. Dakle, možete isplanirati cjelodnevno događanje ili niz kraćih događanja i manjih sastanaka s ključnim dionicima. Kako biste organizirali sveobuhvatnu radionicu preporučujemo planiranje jednodnevnog događanja. Takve su bile SNAP-SEE radionice za savjetovanje koje su trajale između 4 i 8 sati. U sljedećoj tablici predstavljena su još neka razmatranja u vezi s datumom i mjestom događanja.

\begin{tabular}{|c|c|}
\hline ađanja & Mjes \\
\hline $\begin{array}{l}\text { - Što se još održava u to vrijeme - } \\
\text { probajte izbjeći školske praznike, } \\
\text { produžene vikende nastale zbog } \\
\text { državnih praznika usred tjedna, važna } \\
\text { događanja na državnoj/regionalnoj razini } \\
\text { kao što je izborno vrijeme ili druge } \\
\text { popularne događaje kao Svjetsko } \\
\text { prvenstvo ili Olimpijske igre } \\
\text { - Održavaju li se u isto vrijeme slična } \\
\text { događanja koji zahtijevaju istu publiku - } \\
\text { govornici bi već mogli biti zauzeti, a } \\
\text { sudionici neće ići na slično događanje u } \\
\text { tjedan ili dva. } \\
\text { S druge strane - u opravdanim } \\
\text { slučajevima možda želite iskoristiti } \\
\text { priliku i združiti svoj događaj s drugim } \\
\text { koji se održava na istu temu. }\end{array}$ & $\begin{array}{l}\text { - Prometna povezanost do lokacije - je li } \\
\text { lako pristupačna? Postoji li dostupan javni } \\
\text { prijevoz? Ima li dovoljno mjesta za } \\
\text { parkiranje? } \\
\text { - } \quad \text { Koliko dugo su slobodne dvorane za } \\
\text { sastanke? } \\
\text { - Je li dvorana za sastanke dovoljno velika } \\
\text { za očekivani odaziv? } \\
\text { - Je li dvorana prevelika? } \\
\text { - } \quad \text { Ako ćemo održavati radionice na kojima } \\
\text { ce ljudi biti razdvojeni u skupine - ima li } \\
\text { dovoljno prostora za postavljanje } \\
\text { dodatnih radnih skupina? } \\
\text { - Postoji li mjesto gdje se može smjestiti } \\
\text { stol za registraciju? } \\
\text { - Provjeriti ima li lokacija potrebnu tehničku } \\
\text { opremu ili morate donijeti vlastitu. }\end{array}$ \\
\hline
\end{tabular}




\subsection{Surha događanja}

Definiranje cjelokupne svrhe postupka savjetovanja objašnjeno je u poglavlju 3. Prije organiziranja prvog događanja trebamo razmisliti o njegovoj svrsi i ciljanoj publici, a nakon toga će uslijediti određivanje strukture i govornika na događanju.

Prvi ključni korak je određivanje svrhe koja će nas voditi kroz cijeli postupak i biti temelj za odabir prave publike $\mathrm{i}$ odabir najboljih metoda prezentacije ili suradnje sudionika. Kako biste točno odredili svrhu događanja, ovdje se nalaze nekoliko pitanja koja mogu pomoći. Dakle, prije slanja pozivnica sjednite s članovima svojeg tima i razmislite o ovim pitanjima:

$\checkmark$ Što želite postići na kraju događanja - koji su očekivani rezultati (npr., obavještavanje ključnih dionika o projektu i njegovim rezultatima; povećanje kapaciteta SARM, SSM i drugih važnih tema; dogovaranje ključnih koraka i odgovornosti za pripremu državnog plana o mineralnim sirovinama).

$\checkmark$ Koje informacije želite podijeliti, što bi trebala biti glavna poruka događanja? Koje koristi će sudionici imati od događanja? (npr., zaposlenici u ministarstvima će bolje poznavati projekte SARM \& SSM, podatke i metode, primjere pozitivnih slučajeva iz drugih država).

$\checkmark$ Koje opipljive učinke/proizvode želite dobiti na kraju događanja/koje povratne informacije želite primiti od sudionika (npr., popis uskih grla u primjeni postojećih postupaka za koncesije, popis prepreka koje sprječavaju upotrebu recikliranih agregata.)

$\checkmark \quad$ Kako ćete iskoristiti rezultate/učinke događanja (npr., za pripremu preporuka za državna/regionalna nadležna tijela).

Različite potrebe dionika utječu na koji će se način sa svakim od njih komunicirati na događanjima. Zbog toga je važno što bolje razumjeti vaše ciljne skupine, kao što je opisano u poglavlju 4. Na kraju, vrijeme je da se odredi datum, mjesto, svrha i druge ključne informacije o prvom savjetodavnom događanju u Predlošku 5.

Predložak 5: Ključne informacije za prvo savjetodavno događanje

\section{KLUČNE INFORMACIJE ZA PRVO DOGAĐANJE}

Datum događanja:

Lokacija, mjesto događanja:

Svrha i vrsta događanja:

Je li to seminar, razmjena informacija? Je

li to mjesto za prikupljanje mišljenja? Je li

to osmišljeno za prikupljanje ideja $i$

prijedloga? Je li to kombinacija

navedenog?

Trajanje:

Očekivani broj sudionika: 


\subsection{Kako strukturirati događanje}

Jednom kada smo odredili svrhu događanja možemo početi planirati detaljnu strukturu. Postoji nekoliko mogućnosti kako najbolje strukturirati događanje. Obično se koristi jedna od tri mogućnosti ili njihova kombinacija, što je također bio slučaj za SNAP-SEE savjetovanja:

$\checkmark$ Opće prezentacije i prezentacije o jačanju kapaciteta;

$\checkmark$ Moderirana rasprava: za prikupljanje informacija/mišljenja sudionika možemo pripremiti pitanja za moderiranu raspravu; i

$\checkmark$ Radionica $s$ aktivnim sudjelovanjem sudionika: možemo koristiti različite metode kako bismo potaknuli aktivno sudjelovanje većine sudionika i omogućili im da se njihovo mišljenje čuje.

\subsubsection{Opće prezentacije}

Opće prezentacije koriste se na početku događanja te za predstavljanje određene teme sudionicima. Obično, događanje započinje prezentacijom okvirnog rada, npr., projektom unutar kojeg je organizirano, kao i u kojoj fazi je projekt te kako će radionica doprinijeti njegovoj provedbi. Uvodni dio usredotočuje se na sljedeće:

$\checkmark$ Pružanje važnih informacija o projektu, glavnim ciljevima i očekivanim rezultatima projekta;

$\checkmark$ Obavještavanje sudionika o postupku uključivanja dionika, njegovim ciljevima, fazi u kojoj je postupak; i

$\checkmark$ Obavještavanje sudionika o željenom ishodu radionice i kakav će biti njen doprinos.

\subsubsection{Prezentacije o jačanju kapaciteta}

Jedan od ciljeva projekta SNAP-SEE bio je povećati sposobnosti dionika u određenim temama. Ako pristup planiranju agregata želimo učiniti održivim, važno je obratiti se mjerodavnim osobama $\mathrm{i}$ upoznati ih $\mathrm{s}$ projektom. Zbog toga je $\mathrm{u}$ projektu pripremljeno nekoliko prezentacija o jačanju kapaciteta $s$ različitim temama na engleskom jeziku te prevedeno na 11 jezika država jugoistočne Europe. Navedene su u okviru ispod i dostupne za preuzimanje na web stranici projekta http://snapsee.eu. 
Popis prezentacija o jačanju kapaciteta dostupan na engleskom jeziku i jezicima jugoistočne Europe:

1. Održivo planiranje agregata u jugoistočnoj Europi (prezentacija projekta SNAP-SEE i prethodnog projekta SARMa)

2. Osiguravanje Održive mješovite opskrbe agregata (SSM)

3. Pravni i regulatorni okvir za opskrbu agregata na razini EU

4. Agregati: planiranje - potražnja - podaci - "zelena" javna nabava

5. Recikliranje agregata i povezani podaci

6. Sustav izvješćivanja o agregatima i Geografski informacijski sustav kao podrška učinkovitosti resursa; primjer iz GIS sustava

7. Izračun protoka materijala

8. Predviđanja potražnje za agregatima

9. Modeliranje odlučivanja

10. EU politika "zelene" javne nabave (GPP) i Kriteriji cestovnih prioriteta

11. Održivo planiranje kamenih agregata - pristup životnog ciklusa

\subsubsection{Moderirana rasprava}

Drugi cilj savjetovanja je prikupljanje povratnih informacija o različitim aspektima planiranja agregata od sudionika događanja. To se može napraviti moderiranom raspravom ili interaktivnim radionicama sa sudionicima. Odabir metode ovisi o nekoliko karakteristika: broju sudionika, željenom ishodu, vještinama moderatora/voditelja itd. Usporedba obje metode prikazana je u nastavku teksta.

Želimo li raspravljati sa/o svim sudionicima moramo se dobro pripremiti kako bismo mogli moderirati raspravu na prigodan način i dobiti odgovore na pitanja koja želimo znati. Prijedlozi za moderiranje rasprave uključuju:

$\checkmark$ Dobro upoznajte publiku - čije sudjelovanje očekujete, koja će biti njihova mišljenja? Što ih je privuklo na događanje? Na koja pitanja se nadaju dobiti odgovore?

$\checkmark$ Dopustite si dovoljno vremena za prethodnu pripremu, uključujući i trenutna događanja, stručnost govornika i široko poznavanje teme.

$\checkmark$ Pažljivo odaberite moderatora rasprave - nekoga s iskustvom i znanjem o temi.

$\checkmark$ Pripremite unaprijed otvorena pitanja koja predstavljaju probleme sudionika i koja će ih zanimati.

$\checkmark$ Umjesto da sami postavljate svako pitanje, dopustite govornicima i sudionicima raspravu o otvorenim problemima.

$\checkmark$ Uloga moderatora je usmjeriti razgovor, održati pristojan ton, držati sudionike na temi i osigurati da svatko dobije dovoljno vremena predstaviti svoje stajalište. Svrha moderatora nije da daje službenu prezentaciju ili iznosi svoje mišljenje. 
Na savjetovanjima projekta SNAP-SEE, teme za raspravu bile su povezane sa cjelokupnom svrhom: što treba učiniti da se planiranje agregata u našoj zemlji/regiji učini održivijim. To uključuje sljedeća pitanja:

$\checkmark \quad$ Kakvo je trenutno stanje u planiranju; koji su problemi, uska grla, praznine?

$\checkmark \quad$ Tko je zadužen za planiranje agregata? Surađuju li međusobno razna nadležna tijela? Ako da, kako to funkcionira? Ako ne, zašto? Tko blokira suradnju?

$\checkmark \quad$ Koji su postupci? Jesu li prespori? Ako jesu, zašto?

$\checkmark \quad$ Koje su ključne prepreke prema mišljenju industrije?

$\checkmark \quad$ Koji su glavni problemi uočeni od strane nevladinih organizacija, lokalnih zajednica i stanovništva?

$\checkmark \quad$ Koji su prijedlozi za prevladavanje ovih prepreka?

$\checkmark \quad$ Koji nam slučajevi iz drugih zemalja mogu poslužiti kao primjer (prikladno prilagođeni situaciji druge zemlje/regije) za rješavanje problema?

$\checkmark$ Koja rješenja treba primjenjivati, pod kojim uvjetima, tko ih treba primjenjivati, u kojem vremenskom okviru?

\subsubsection{Radionica s aktivnim sudjelovanjem sudionika}

Druga mogućnost je organiziranje dijela događanja više na interaktivan način podijeliti sudionike u nekoliko skupina i prikupiti povratne informacije iz svake skupine posebno. Ovaj pristup je prikladan za manja događanja (do 50 osoba), jer je potreban veći broj moderatora/voditelja. Prvo ćemo pogledati usporedbu između plenarne sjednice (prezentacije ili moderirane rasprave) i interaktivne radionice.

\section{USPOREDBA IZMEĐU RADA U PLENUMU I RADA U MANJIM SKUPINAMA}

Rad u plenumu je učinkovit za održavanje prezentacije, ali nije tako učinkovit ako je cilj opširna rasprava. Održavanje rasprave u plenumu ima sljedeće nedostatke:

$\checkmark$ Nekoliko sudionika će dominirati - većina neće sudjelovati.

$\checkmark$ Što je veća skupina, manje sudionika ima dovoljno samopouzdanja izraziti svoje mišljenje.

$\checkmark \quad$ Oni koji izraze svoje mišljenje osjećati će se ograničeno u svom izričaju.

Rad u manjim skupinama bolji je u sljedećim okolnostima:

\footnotetext{
$\checkmark \quad$ Kada je skupina prevelika da svatko izrazi svoje mišljenje.

$\checkmark \quad$ Kada je potrebna opširna rasprava.

$\checkmark \quad$ Kada se omogući manje samouvjerenim sudionicima da izraze svoje mišljenje.

$\checkmark$ Za izgradnju više povjerenja i razumijevanja između dionika.
} 
Kada se planira rad u skupinama, treba imati na umu da će sudionici najbolje raditi u skupinama od 7 do 10 pojedinaca. Sudionici se mogu prijaviti u skupinu u koju žele ili ih se može rasporediti na osnovi metoda opisanih u poglavlju 6.

\section{Kako voditi interaktivnu radionicu}

Prije početka radionice morate odlučiti hoćete li sudionike podijeliti u skupine i koliko ćete skupina odrediti, zatim odabrati tehniku pomoću koje ćete prikupiti informacije te potom predstaviti rezultate radionice svim sudionicima. Nakon podjele u skupine upotrebljavajte tehniku koja će vam omogućiti da dobijete što više odgovora, ideja i prijedloga o jednoj određenoj tematici. $U$ ovom trenutku morate biti oprezni u sljedećem:

$\checkmark$ Jasno recite svrhu radionice; koji su očekivani ishodi.

$\checkmark$ Jasno definirajte pitanja na koja želite dobiti odgovore sudionika.

Ako imate druga pitanja koja su povezana s temom i želite odgovore svih sudionika na sva pitanja, možete se poslužiti s dvije metode koje se mogu primijeniti vrlo lako i omogućavaju da u kratkom vremenu obavite puno - vrtuljak ideja i "World Café". Detalji su opisani u poglavlju 6.

U ovom trenutku treba razmisliti o strukturi događanja $s$ dionicima. Od kojih dijelova će se sastojati? Kako će se međusobno pratiti? Tko će biti govornici? O čemu želimo raspravljati? Što želimo znati na kraju rasprave? Trebaju li nam materijali kao što su brošure, upitnici, papirnati blokovi i olovke itd.? Odgovori bi se trebali nalaziti ispod u Predlošku 6.

\section{Predložak 6: Struktura događanja}

\begin{tabular}{|l|l|l|l|}
\hline STRUKTURA DOGAĐANJA & $\begin{array}{l}\text { Naslov, } \\
\text { cilj }\end{array}$ & $\begin{array}{l}\text { Potencijalni } \\
\text { govornici }\end{array}$ & $\begin{array}{l}\text { Potrebni } \\
\text { materijali }\end{array}$ \\
\hline Dio događanja & & & \\
\hline Uvodna prezentacija & & & \\
\hline Jačanje kapaciteta, sjednica 1 & & & \\
\hline Jačanje kapaciteta, sjednica 2 & & & \\
\hline Jačanje kapaciteta, sjednica 3 & & \\
\hline Rasprava/prikupljanje informacija, sjednica 1 & & & \\
\hline Rasprava/prikupljanje informacija, sjednica 2 & & & \\
\hline$\ldots$ & & & \\
\hline$\ldots$ & & & \\
\hline
\end{tabular}




\subsection{Priprema dnevnog reda i pozivnica}

Do sada smo odredili ključne parametre događanja - svrhu, vrijeme i mjesto sjednice. Vrijeme je za pripremu dnevnog reda i pozivnica za sudionike.

\subsubsection{Dnevni red događanja}

Kada se priprema dnevni red događanja prvo treba odrediti vrijeme početka i završetka - treba uzeti u obzir koliko će vremena trebati sudionicima da dođu do mjesta održavanja te koliko će vremena biti potrebno prije događanja za pripremu dvorane. Sljedeći korak je osigurati slobodno vrijeme - na svakom događanju uvijek trebate imati vrijeme za pauze, početne i završne aktivnosti i uvodne prezentacije.

\section{Stanka}

Stanke su sastavni dio svakog događanja. Potrebne su zbog toga jer:

$\checkmark$ Omogućuju vrijeme za neformalna druženja sudionika.

$\checkmark$ Razbijaju napetost i omogućuju vrijeme za neformalne razgovore ili za nastavak nekih rasprava koje su započele tijekom sjednica - to je posebno važno za vrijeme zajedničkog ručka.

$\checkmark$ Sudionicima daju mogućnost odmora između tema i zasjedanja te na taj način poboljšavaju koncentraciju i energiju.

\section{Početne i završne aktivnosti}

Na početku svakog događanja planirajte vrijeme za sljedeće aktivnosti:

$\checkmark$ Okupljanje sudionika, registraciju;

$\checkmark \quad$ Ako je moguće ponudite čaj/kavu ili neko osvježenje tijekom registracije tako sudionicima dajete priliku za uključivanje u neformalni razgovor koji može pomoći pri izgradnji dobre radne atmosfere i izgradnji povjerenja između sudionika;

$\checkmark$ Pozdravni govor predstavnika domaćina i važnih gostiju - na primjer načelnika općine, predstavnika ministarstva nadležnog za temu događanja itd.;

$\checkmark$ Predstavljanje voditelja i govornika;

$\checkmark$ Pregled dnevnog reda i tijeka događanja, određivanje mjesta gdje će se održati stanke, gdje će biti poslužena osvježenja, gdje su toaleti, i ostale bitne informacije;

$\checkmark$ Objašnjenje kako će se voditi događanje, posebno ako planirate interaktivne radionice - objasnite kako će biti organiziran rad u skupinama, tko će voditi radne skupine itd.;

$\checkmark$ Objašnjenje za materijale koje ste im podijelili; i 
$\checkmark \quad$ Ako je skupina dovoljno mala i planirate interaktivno događanje dobro je održati uvodni krug kako bi se sudionici međusobno upoznali. Inače, to možete učiniti i kasnije kada će se raditi u skupinama.

Na kraju svakog događanja potrebno je vrijeme za sljedeće:

$\checkmark$ Zaključke s događanja;

$\checkmark$ Objašnjenje sljedećih koraka - kada će primiti izvješće sa događanja, koji su sljedeći rokovi;

$\checkmark$ Ako je bitno - kada će se održati sljedeće događanje; i

$\checkmark$ Završni govor - zahvala sudionicima na dolasku.

Nakon što smo sve ovo isplanirali možemo vidjeti koliko nam je vremena ostalo za sjednice koje će se usredotočiti na teme događanja. U nastavku teksta, u Predlošku 7, možete vidjeti primjer dnevnog reda.

\section{Predložak 7: Dnevni red SNAP-SEE savjetodavnog događanja}

\begin{tabular}{|c|c|c|}
\hline Vrijeme & Tema & Govornici \\
\hline $9.00-9.30$ & Registracija i čaj/kava dobrodošlice & \\
\hline $9.30-9.40$ & Uvodni pozdrav & Govornik 1 \\
\hline $9.40-9.50$ & $\begin{array}{l}\text { Uvod, predstavljanje dnevnog reda, govornika, } \\
\text { raspored dana }\end{array}$ & Moderator \\
\hline $9.50-10.05$ & $\begin{array}{l}\text { Predstavljanje projekta/razlozi } \\
\text { sudjelovanja }\end{array}$ & Moderator \\
\hline $10.05-10.20$ & $\begin{array}{l}\text { Projekt SNAP-SEE u mojoj zemlji/regiji - glavne } \\
\text { aktivnosti i rezultati, ciljevi savjetovanja }\end{array}$ & Govornik 2 \\
\hline $10.20-10.40$ & Jačanje kapaciteta sjednica 1 i 2 & Govornici 3, 4 \\
\hline $10.40-11.00$ & Pauza za kavu & \\
\hline $11.00-11.30$ & Jačanje kapaciteta sjednica 3 i 4 & Govornici 5, 6 \\
\hline $11.30-12.30$ & $\begin{array}{l}\text { Rasprava/prikupljanje informacija sjednica 1: Tema } 1 \\
\text { (rasprava ili grupni rad na zadanu temu) }\end{array}$ & $\begin{array}{l}\text { Moderator ili } \\
\text { voditelj }\end{array}$ \\
\hline $12.30-13.30$ & Ručak & \\
\hline $13.30-14.15$ & $\begin{array}{l}\text { Rasprava/prikupljanje informacija sjednica 2: Tema } 2 \\
\text { (rasprava ili grupni rad na zadanu temu) }\end{array}$ & $\begin{array}{l}\text { Moderator ili } \\
\text { voditelj }\end{array}$ \\
\hline $14.15-14.40$ & Izvješće skupina i zajednička rasprava & $\ldots$ \\
\hline $14.40-15.00$ & Završna sjednica & $\ldots$ \\
\hline 15.00 & Završetak & \\
\hline
\end{tabular}

Odredili smo pregled događanja. lako možda nemamo detaljan plan svake pojedine sjednice, znamo probleme i teme o kojima želimo raspravljati i sljedeći korak je priprema i slanje pozivnica. 


\subsubsection{Pozivnice}

Primamljiva pozivnica je ključ uspješnog događanja. Jasna, kratka, jezgrovita, ali u isto vrijeme razumljiva, pozivnica treba izazvati znatiželju i privući sudionike da dođu na događanje. Možete imati isplaniran odličan program te značajne i važne stvari za reći, ali sve će to ostati neispričano ako nije dobro priopćeno ciljanim sudionicima.

Dobro pripremljena pozivnica treba sadržavati:
$\checkmark$ Naslov događaja;
$\checkmark \quad$ Kratke pozadinske informacije o događanju - je li dio većeg projekta, kojeg i kako se ovo događanje uklapa u taj projekt;
$\checkmark \quad$ Koja je ciljana publika i što će dobiti ako sudjeluju;
$\checkmark \quad$ Koji je cilj događanja, koji su očekivani ishodi, kako će se dalje koristiti i tko će in koristiti;
$\checkmark$ Dnevni red događanja;
$\checkmark$ Informacije o tome kako i gdje se registrirati te koji su rokovi za registraciju;
$\checkmark$ Detalji o kontaktu gdje sudionici mogu dobiti dodatne informacije o događanju - popis e-mail adresa i telefonskih brojeva kontakt osobe;
$\checkmark$ Informacije o mjestu održavanja i (ako je važno) kako doći do mjesta održavanja te ostale potrebne informacije.

Nema čarobne formule za sastavljanje dobre pozivnice. Važno je prilagoditi pozivnicu ciljanoj publici koristeći tečan i razumljiv jezik.

Ostavite dovoljno vremena za planiranje događanja:

$\checkmark$ Počnite pripremati državno/regionalno događanje 6-8 tjedana prije događanja.

$\checkmark$ Pošaljite pozivnice ili barem kratku obavijest o događaju 4-6 tjedana prije događanja.

$\checkmark$ Pošaljite podsjetnik i detaljan dnevni red (ako ga niste već prije poslali) svim uzvanicima 1-2 tjedna prije događanja i opet 2 dana prije događanja.

$\checkmark$ Za međunarodno događanje trebate početi planirati i do 6 mjeseci prije kako biste dobili željene govornike, a osobito ako planirate održati stručnu konferenciju gdje želite predstaviti stručne radove; pošaljite pozivnice 3 mjeseca prije; ne zaboravite poslati podsjetnike kada se približi datum događanja - 1 mjesec prije i 2 tjedna prije za registraciju u zadnjem trenutku. 


\subsection{Detaljan plan događanja}

Nakon što ste poslali pozivnice možete se usredotočiti na pripremu detaljnog plana događanja. To zapravo znači pripremu scenarija o tome kako provoditi događanje da bi svi u timu bili u toku. To također znači definiranje detaljnijih tema za raspravu i/ili odabir tehnika i metoda rada u interaktivnim radionicama. Nakon što ste razjasnili sva ova pitanja napišite detaljan plan i pobrinite se da ga imaju svi u vašem timu. Tablicu s detaljnim planom događanja možete naći u nastavku u Predlošku 8.

Predložak 8: Detaljan plan poludnevnog događanja

\begin{tabular}{|c|c|c|c|}
\hline Vrijeme & Tema i korištene tehnike & Tko & Materijali \\
\hline $8.00-9.00$ & $\begin{array}{l}\text { Priprema dvorane: } \\
\text { - Postavljanje plakata } \\
\text { - Pripremanje stola za } \\
\text { registraciju i materijala za } \\
\text { sudionike } \\
\text { - Pripremanje računala i } \\
\text { projektora te spremanje PPT } \\
\text { prezentacija na računalu itd. }\end{array}$ & Cijeli tim & $\begin{array}{l}\text { - Plakati } \\
\text { - Popis prisutnih } \\
\text { sudionika } \\
\text { - Materijali } \\
\text { - Prijenosno } \\
\text { računalo } \\
\text { - Projektor } \\
\text { - Papirnati } \\
\text { blokovi } \\
\text { - } \text { Itd. }\end{array}$ \\
\hline \multirow[t]{2}{*}{$9.00-9.30$} & $\begin{array}{l}\text { Registracija i kava dobrodošlice } \\
\text { - Davanje popisa prisutnih } \\
\text { sudionika na potpis } \\
\text { - Dijeljenje materijala } \\
\text { - Posluživanje kave i keksa }\end{array}$ & $\begin{array}{l}\text { Članovi tima } \\
\text { Usluge } \\
\text { organiziranja } \\
\text { domjenka }\end{array}$ & $\begin{array}{l}\text { - Materijali } \\
\text { - Popis prisutnih } \\
\text { sudionika }\end{array}$ \\
\hline & $\ldots$ & & \\
\hline \multirow[t]{2}{*}{$9.40-9.50$} & $\begin{array}{l}\text { Uvod, predstavljanje dnevnog } \\
\text { reda, govornika, kako će } \\
\text { funkcionirati dan }\end{array}$ & Glavni moderator & $\begin{array}{l}\text { - } \text { PPT s dnevnim } \\
\text { redom }\end{array}$ \\
\hline & $\ldots$ & & \\
\hline \multirow[t]{2}{*}{$10.20-10.40$} & Jačanje kapaciteta sjednica 1 i 2 & $\begin{array}{l}\text { Govornik } 1 \\
\text { Govornik } 2 \\
\end{array}$ & $\begin{array}{l}\text { - PPT } \\
\text { - Brošure? }\end{array}$ \\
\hline & $\ldots$ & & \\
\hline \multirow[t]{2}{*}{$11.00-12.30$} & $\begin{array}{l}\text { Prezentacija 1: Tema } 1 \\
\text { 1. dio, tehnike: Vrtuljak: Rad u } 3 \\
\text { skupine; pitanja za skupine: } \\
\text { - Pitanje } 1 \\
\text { - Pitanje } 2 \\
\text { - Pitanje } 3 \\
\text { 2. dio, tehnike: Prioritete označiti } \\
\text { točkom }\end{array}$ & $\begin{array}{l}\text { Glavni moderator } \\
\text { Moderatori } \\
1,2,3\end{array}$ & $\begin{array}{l}\text { - Papirnati } \\
\text { blokovi - } 5 \text { po } \\
\text { skupini } \\
\text { - } 3 \text { različite } \\
\text { olovke u boji } \\
\text { - Točke u boji } \\
\text { - } . . .\end{array}$ \\
\hline & $\ldots$ & & \\
\hline $12.30-13.00$ & Završetak događanja & Glavni moderator & - Zaključci \\
\hline
\end{tabular}


Ovaj plan možete učiniti onoliko detaljnim koliko vam je potrebno - možete dodati detaljan opis svakog koraka pojedine tehnike/metode. To će biti jako korisno u slučaju kada pojedinu metodu koristite po prvi put. Preispitajte plan nakon nekoliko dana i napravite plan B i C u slučaju da previdite neke probleme - na primjer ako dođe manje sudionika nego što ste planirali i ne budete li mogli raditi u skupinama koja je moguća alternativa?

\section{Planiranje savjetodavnog događanja - iskustvo projekta SNAP-SEE:}

$\checkmark$ Događanje trebamo početi planirati dosta unaprijed (bar 3 mjeseca) kako bismo privukli zanimljive govornike i motivirali dolazak sudionika.

$\checkmark$ Trebamo paziti da ne organiziramo događanje vrlo blizu državnih praznika, jer ljudi imaju običaj uzeti koji dan više odmora.

$\checkmark$ Na pozivnici trebamo jasno navesti svrhu događanja te da će biti prikupljeni odgovori sudionika na odabrane teme.

$\checkmark$ Trebao bi biti odgovarajući broj sudionika za rad u skupinama (ne previše i ne premalo, između 20 i 60 ).

$\checkmark \quad$ Ne treba pretjerivati s brojem prezentacija jer će se sudionici umoriti i možda čak i ranije otići.

$\checkmark$ Trebamo vrlo oprezno odrediti što bismo željeli saznati tijekom rasprave ili tijekom grupne vježbe. Sposoban i dobro pripremljen moderator (i/ili voditelj) ima ključnu ulogu u postizanju uspješnog ishoda rasprave.

$\checkmark \quad$ Stanke za kavu i ručak su povoljne prilike za sudionike, koji predstavljaju različite ciljane skupine, da nastave raspravu i neformalno druženje. 


\section{Tehnike za interaktivne radionice}

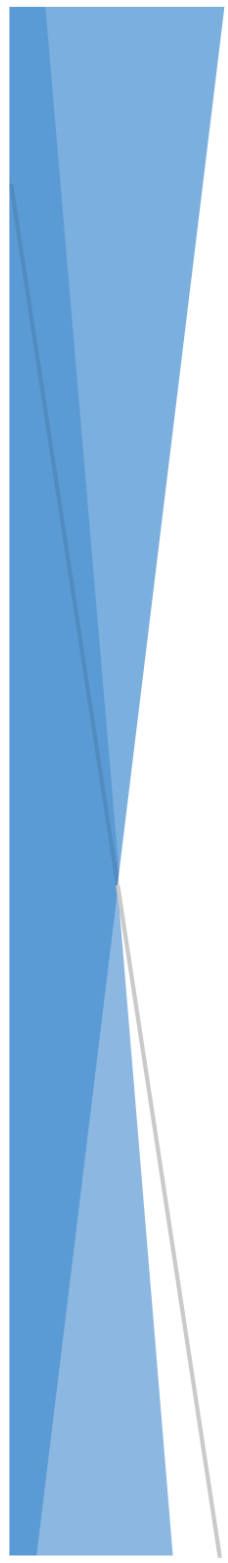

Rasprava u manjim skupinama ima brojne prednosti. U ovom poglavlju predstavljene su pojedine tehnike korištene na interaktivnim radionicama. Zapravo, nema recepta o tome kako odabrati prave tehnike/metode za vođenje radionice; ovo je kreativni dio cijelog postupka gdje se možemo igrati našim idejama kako bismo sastavili niz akcija koje će nas dovesti do zadanog cilja.

Ključ je pronaći najprikladnije tehnike/metode kako bismo postigli ono što želimo, u vremenu koje imamo na raspolaganju za pojedina zasjedanja.

Na SNAP-SEE događanjima iskustvo je pokazalo kako rasprave u malim skupinama, od 7 do 10 osoba, imaju nekoliko prednosti, npr., više ljudi sudjeluje u raspravi, veća je razmjena mišljenja i iskustava, a prepoznata su $i$ različita rješenja koja su zatim i unaprijeđena. 


\subsection{Prije početka}

Na savjetodavnom događanju, rad u skupinama ima brojne prednosti i može dovesti do rezultata koji nadahnjuju, što je bio i slučaj na SNAP-SEE događanju. Može se koristiti nekoliko tehnika/metoda, a moraju se odabrati na temelju naših ciljeva. Moramo odlučiti:

$\checkmark$ Hoćemo li raditi u jednoj ili više skupina;

$\checkmark$ Hoće li svaka skupina raditi na istom problemu/pitanju ili će svaka skupina imati vlastitu temu;

$\checkmark \quad$ Na koji način ćemo podijeliti sudionike u skupine;

$\checkmark \quad$ Napraviti popis prikladnih tehnika/metoda i onda ih usporediti s dostupnim vremenom, prostorom i moderatorom - na temelju ovoga možete se odlučiti za onu koja vam se čini najprikladnijom; i

$\checkmark$ Odlučiti kako će biti organizirana dvorana za interaktivni dio događanja.

Osim toga, trebamo odlučiti o:

$\checkmark$ Potrebnim materijalima: papirnatim blokovima, kemijskim olovkama itd.;

$\checkmark$ Materijalima koje će trebati moderator;

$\checkmark$ Materijalima koje treba pripremiti i podijeliti sudionicima; i

$\checkmark$ Podjela uloga organizacijskog tima na događanju: tko će biti glavni moderator, tko će biti voditelji u skupinama, tko će bilježiti što se govori, tko će se brinuti o praktičnim rješenjima.

\subsection{Podjela sudionika u skupine}

Odluka da sami podijelimo sudionike u skupine ima svoje prednosti u tome da raspoređuje ljude iz istih organizacija ili one sličnih interesa. Ovako formirane skupine su puno „šarenije“ od skupina nastalih njihovim vlastitim izborom, jer će ljudi sličnih stavova izbrati slične skupine.

\section{Kako grupirati sudionike:}

$\checkmark$ Označite sudionike brojevima, te zamolite sve "jedinice" da odu u radni prostor jedan, sve "dvojke" da odu u radni prostor dva, itd. Sudionici iz istih organizacija obično sjede/stoje zajedno, pa će te ih na ovaj način pomiješati.

$\checkmark$ Dajte sudionicima slučajno odabranu boju ili oblik pri registraciji te in na taj način podijelite u skupine. To možete učiniti tako da zalijepite točkicu u boji na oznaku s imenom ili da su oznake s imenom različitih boja. Onda zamolite sve sudionike $s$ narančastom bojom da odu u jednu skupinu, s crvenom bojom u drugu skupinu itd.

$\checkmark \quad$ Ovo je posebno korisno ako želite pomiješati različite sektore. Dajte svakom sektoru jednu boju i onda možete pomiješati skupine te tako ograničiti broj „zelenih“, „plavih“, itd. 
$\checkmark \quad$ Ako vam nije bitno kako ćete ih podijeliti možete in jednostavno podijeliti tako što ćete staviti prvih deset osoba koje sjede zajedno u jednu skupinu, sljedećih deset u drugu, itd.

\section{3 "Vrtuljak ideja"}

Vrtuljak ideja (brainstorming) je korisna metoda za stvaranje velikog broja odgovora na pitanja u kratkom vremenu. Njegove prednosti su:

$\checkmark$ Omogućuje istraživanje raznovrsnih pogleda na postavljeno pitanje.

$\checkmark \quad$ Kretanje u krug po stanicama s različitim pitanjima omogućuje prikupljanje različitih prijedloga.

$\checkmark$ Rad u skupinama potiče na razgovor one koji su malo stidljiviji.

$\checkmark$ Omogućuje procjenu sveukupnog znanja skupine ljudi o određenom pitanju.

$\checkmark$ Riječ je o fizički aktivnoj sjednici, zbog čega će nastati energična atmosfera.

Vrtuljak može koristiti do 60 sudionika podijeljenih u 6 različitih skupina od 10 osoba. U nastavku je prikazano pet koraka za njegovu primjenu.

\begin{tabular}{|c|c|}
\hline \multicolumn{2}{|c|}{$\begin{array}{l}\text { Kako voditi vrtuljak ideja - korišteno na SNAP-SEE savjetovanjima za prikupljanje mišljenja } \\
\text { dionika }\end{array}$} \\
\hline $\begin{array}{l}\text { 1. Odlučite se } o \\
\text { broju skupina }\end{array}$ & $\begin{array}{l}\text { - } 1 \text { skupina = } 1 \text { pitanje. } \\
\text { - Možete se služiti pitanjima ponuđenim u nastavku teksta ili } \\
\text { sastavite nova/dodatna, osmišljena na temu projekta. } \\
\text { - Tehnikom vrtuljka može se upravljati sa do } 6 \text { pitanja/skupina. }\end{array}$ \\
\hline $\begin{array}{l}\text { 2. Podijelite } \\
\text { sudionike u } \\
\text { skupine }\end{array}$ & $\begin{array}{l}\text { - Možete koristiti metode navedene u poglavlju } 6.2 \text { za podijelu } \\
\text { sudionika u skupine. }\end{array}$ \\
\hline $\begin{array}{l}\text { 3. Odradite } \\
\text { vrtuljak ideja }\end{array}$ & 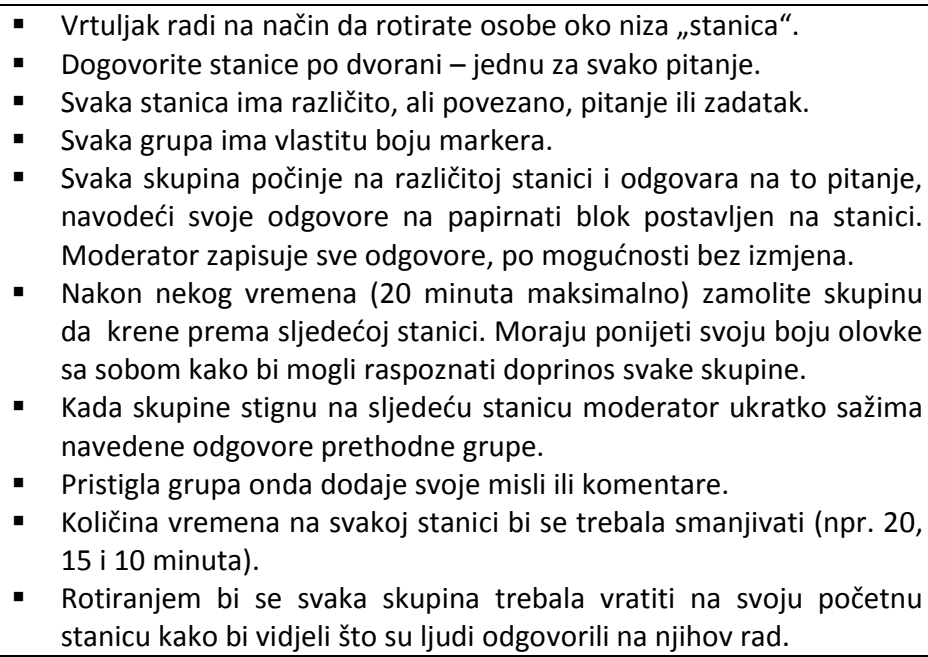 \\
\hline
\end{tabular}




\begin{tabular}{|l|l|}
\hline & $\begin{array}{l}\text { - Proces završava onda kada sve skupine odgovore na sva pitanja. } \\
\text { - } 45-60 \text { minuta obično je dovoljno vremena za tri ili četiri skupine, do } \\
\text { sat i pol za najviše šest stanica. }\end{array}$ \\
- $\begin{array}{l}\text { Na kraju, voditelji svake skupine mogu sažeti ključna saznanja } \\
\text { cjelokupnoj publici. }\end{array}$ \\
\hline $\begin{array}{l}\text { Materijali koji će } \\
\text { vam biti potrebni }\end{array}$ & $\begin{array}{l}\text { - Olovke u boji (druga boja za svaku grupu) } \\
\text { - Papirnati blok ili ljepljiva guma koja lijepi papir na zid bez } \\
\text { ostavljanja tragova. }\end{array}$ \\
\hline $\begin{array}{l}\text { Kako snimiti } \\
\text { zaključke }\end{array}$ & $\begin{array}{l}\text { Slikajte popunjene papirnate blokove i/ili ih ponesite kući. } \\
\text { Upotrijebite ih za zaključke u izvještaju s događanja kao doprinos } \\
\text { vašem budućem radu. }\end{array}$ \\
\hline
\end{tabular}

\section{4 "World Café"}

Jedna od raznolikosti vrtuljaka jest takozvana metoda "World café". Ovo je jednostavna metoda za poticanje razgovora između sudionika o određenim pitanjima. Metoda omogućava prikupljanje ideja i iskustava svakog člana skupine u kratkom vremenskom periodu (1-2 sata). Osnovne karakteristike ove metode su:

$\checkmark$ Jedan stol za jedno pitanje, sudionici sjede oko svakog stola.

$\checkmark$ Postavite papirnate ploče i markere (svaka skupina ima drugu boju).

$\checkmark \quad$ Na stol stavimo grickalice, kekse i kavu kako bi okruženje sličilo kafiću metoda oponaša opuštenu raspravu u kafiću.

$\checkmark$ Jednu osobu iz svake skupine (ili moderatora) proglasite "domaćinom stola" te on ostaje za stolom tijekom cijelog procesa.

$\checkmark$ Nakon 20 minuta rasprave skupine mijenjaju stolove.

$\checkmark$ Domaćin stola ukratko predstavlja rezultate prethodne skupine, a onda oni mogu početi iznositi svoje odgovore.

$\checkmark$ Možete odabrati isto pitanje u svim skupinama. U tom slučaju sudionici ostaju za svojim stolom cijelo vrijeme i ne kreću se uokolo.

Upotreba metoda interaktivne rasprave na SNAP-SEE događanjima: korištene su obje metode, vrtuljak ideja i "world café". Postavljeno je nekoliko različitih pitanja, očekujući od sudionika povratnu informaciju o problemima s planiranjem agregata u njihovoj zemlji i specifične teme (npr. kako integrirati primarno i sekundarno planiranje; kako eksploataciju učiniti manje štetnom za prirodu, kako motivirati lokalne zajednice da prihvate eksploataciju, itd.). Osim toga, pitali smo koja su moguća rješenja, koraci prema tim rješenjima i koje bi se organizacije trebale brinuti o njima. Na kraju, upotreba interaktivnih metoda bila je vrlo pozitivno iskustvo, jer je više ljudi sudjelovalo u raspravi i podijeljeni su korisni prijedlozi. 


\section{Provedba događanja}

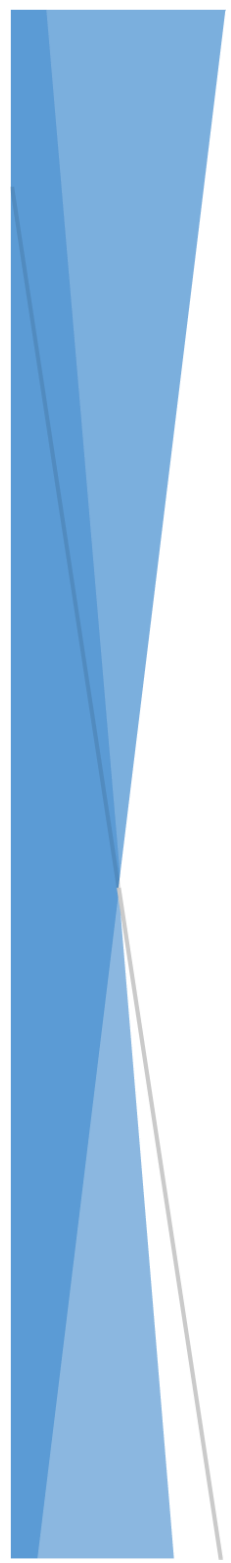

Ključne aktivnosti na dan provedbe događanja uključuju informiranje tima, pripremanje dvorane i praktična rješenja, dobro vođenje i završetak događanja kako bi sudionici otišli s pozitivnim dojmovima.

Na dan održavanja događanja, moramo biti sigurni da će pripremljeni detaljni plan događanja funkcionirati te da će dan proći glatko. To uključuje provjeru plana događanja, informiranje tima i osiguravanje svih praktičnih rješenja.

Jedno od ključnih iskustava sa SNAP-SEE događanja je fleksibilnost - sigurno neće sve teći točno prema planu, ali treba ostati miran, prilagoditi se novim okolnostima $i$ rezultat neće izostati. 


\subsection{Pregled događanja i informiranje tima}

Netom prije početka događanja još jednom pregledajte program sa svojim timom. Pregledajte informiranje tima i upute za sudionike kako biste osigurali da su napisani najjednostavnijim mogućim jezikom. Pobrinite se da svatko u timu zna što se očekuje od njega.

\subsection{Pripremanje dvorane}

Provjerite je li raspored dvorane postavljen kako ste tražili. Raspored stolica i stolova u dvorani za sastanke ovisi o tome kako će sadržaj biti predstavljen sudionicima. Odaberite dvoranu koja će vam pomoći postići ciljeve za vaše događanje. Raspored dvorane najčešće je prepušten slučaju, ali gdje i kako će ljudi sjediti znatno utječe na tijek događanja kako je prikazano u tablici u nastavku teksta.

\begin{tabular}{|c|c|c|}
\hline Kazalište & $\begin{array}{l}\text { Redovi stolica gledaju prema prednjem dijelu } \\
\text { dvorane, obično su podijeljeni po središnjim } \\
\text { prolazima i/ili bočnim prolazima. Omogućava } \\
\text { maksimalnu iskoristivost prostora u dvorani. } \\
\text { Ovaj raspored je dobar kada publika zapisuje } \\
\text { kratke bilješke i/ili kada je trajanje prezentacija } \\
2 \text { sata ili manje. }\end{array}$ & 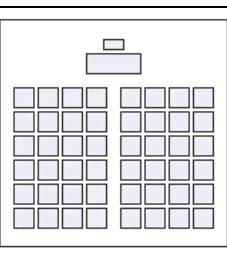 \\
\hline Učionica & $\begin{array}{l}\text { Redovi stolova sa } 2 \text { ili } 3 \text { stolice za svakim } \\
\text { stolom, a stolovi su raspoređeni tako da } \\
\text { gledaju prema prednjem dijelu dvorane. } \\
\text { Prikladno je za konferencije informativnog tipa. } \\
\text { Predavači pružaju publici informacije s malo } \\
\text { dijaloga. }\end{array}$ & \\
\hline U-oblik & $\begin{array}{l}\text { Potiče jednakost i interakciju te omogućuje } \\
\text { predavačima slobodno kretanje prema } \\
\text { pojedinom članu skupine i obraćanje } \\
\text { pojedincima. Ovo je dobar raspored za } \\
\text { rasprave. }\end{array}$ & 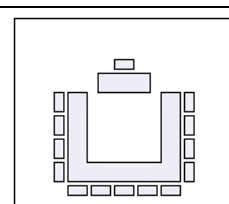 \\
\hline Okrugli stol & $\begin{array}{l}\text { Potiče doprinos svih sudionika ako planirate } \\
\text { imati raspravu tijekom događanja. Ako } \\
\text { planirate imati raspravu sa svim sudionicima } \\
\text { zajedno, onda uklonite stol i stavite samo } \\
\text { stolice u krug. Ako planirate provesti metodu } \\
\text { „world café“ tada pripremite nekoliko manjih } \\
\text { okruglih stolova kao što je prikazano na slici. }\end{array}$ & \\
\hline
\end{tabular}


Osim toga, trebate pripremiti:

$\checkmark$ Prijavljivanje: stol za prijavu, oznake $s$ imenima sudionika i materijale za sudionike;

$\checkmark \quad$ Materijale i opremu u dvorani: plakate, prezentacije, itd.; i

$\checkmark$ Osvježenja s pružateljima ugostiteljskih usluga.

\subsection{Za vrijeme održavanja događanja}

I na kraju - dvorana je spremna, sudionici su stigli i događanje počinje. Dobro ste se pripremili, pa ste mirni i opušteni na početku događanja. Uspjeh događanja sada ovisi o: (a) dobrom vođenju; (b) držanju rasporeda i tema dnevnog reda; i (c) pažljivom zapisivanju onog što se govori, uzimajući u obzir sve sudionike i sve komentare.

\subsection{Moderiranje i moderatori}

Moderiranje interaktivnih radionica $s$ mnogo različitih interesa zahtjeva tim dobro pripremljenih moderatora. Moderiranje je jedna od ključnih vještina u radu $s$ grupama ljudi. Moderator će vrlo jasno predstaviti što se očekuje od skupine, ali ne određuje način na koji će skupina postići rezultate. Vještine dobrog moderatora osim dobrih verbalnih i neverbalnih komunikacijskih vještina - predstavljene su u tablici.

\begin{tabular}{|l|l|}
\hline Slušanje & $\begin{array}{l}\text { Pokažite da vas zanima ono što govore i zašto to govore. Time se stvara } \\
\text { povjerljiva i pogodna atmosfera. }\end{array}$ \\
\hline Ispitivanje & $\begin{array}{l}\text { Postavite prava pitanja pravim ljudima u pravo vrijeme na pravi način. Na } \\
\text { taj ćete način održavati raspravu. }\end{array}$ \\
\hline Preoblikovanje & $\begin{array}{l}\text { Spriječite napetost i negativnost, usredotočujući se na zajedničke ciljeve. } \\
\text { Ova vještina je vrlo bitna kad su česti sukobi ili napetosti u dvorani. }\end{array}$ \\
\hline Prekidanje & $\begin{array}{l}\text { Budite spremni prekinuti pričljive ili agresivne članove skupine ili one koji se } \\
\text { udaljavaju od teme. Pripremite nekoliko unaprijed isplaniranih fraza za } \\
\text { prekidanje. Npr. ako netko prijeđe na temu koja nije korisna glavnoj temi, } \\
\text { možete ga prekinuti i reći: „Imate zanimljivo stajalište, ali željeli bismo znati } \\
\text { više o } \\
\text { njegov prirodni ritam disanja i ubacite se između udaha, „Hvala vam, Ivana. } \\
\text { A sada, da čujemo Markovo viđenje ove teme.“ }\end{array}$ \\
\hline
\end{tabular}

\section{Zapisivanje}

U malim skupinama jedna osoba može biti moderator i bilježiti sve što se govori, ali u većim skupinama savjetujemo da imate dvije osobe, jednu za svaki zadatak. Ključ uspješnog zapisivanja je pružiti sažeti zapis dijaloga, koji je jasan, jednostavan za čitanje i lagan za praćenje. Uhvatite bit i zapišite sve što je rečeno. Neki dodatni savjeti za uspješno zapisivanje: 
$\checkmark$ Slušajte i budite precizni - pokušajte koristiti njihove riječi;

$\checkmark$ Ako niste sigurni, savjetujte se sa sudionicima u vezi pojmova;

$\checkmark \quad$ Ne brinite previše o pravopisu;

$\checkmark \quad$ Na početku svake stavke koristite crticu (-);

$\checkmark \quad$ Stavite broj na svaku navedenu papirni blok; i

$\checkmark$ Služite se dovoljno velikim malim slovima.

\section{Moderator treba:}

- Predstaviti se

- Biti opušten

- Biti samouvjeren

- Koristiti prikladan ton glasa i uvodno pitanje

- Poticati sve na sudjelovanje

- Primjereno reagirati na ono što se priča: potvrđivanjem, poticanjem, pokazivanjem razumijevanja

- Biti zadovoljan tišinom, raditi s njom, ne ju pokušati popuniti

- Odnositi se isto prema svačijim stajalištima

- Nositi se s teškim osobama

- Snimiti sve što je rečeno

\subsection{Završetak događanja}

$\mathrm{Na}$ kraju događanja dogodit će se nekoliko završnih aktivnosti koje uključuju donošenje zaključaka, objašnjavanje sljedećih koraka u postupku ili gdje će se koristiti rezultati radionice, te povratne informacije sudionika. $U$ ovu svrhu može se koristiti upitnik za ocjenjivanje. Podijelimo ga svim sudionicima na kraju događanja te zatražimo njihovo mišljenje o nekoliko pitanja: je li događanje ispunilo njihova očekivanja, jesu li naučili nešto novo, jesu li imali priliku postaviti pitanja ili iznijeti svoje stavove, je li događanje prikladno organizirano, imaju li prijedloge za buduća događanja, itd.

\section{Završavanje događanja:}

$\checkmark$ Održite završni govor, odgovorite na neodgovorena pitanja.

$\checkmark$ Jasno recite kako i gdje će rezultati s radionice biti upotrijebljeni, koji su sljedeći koraci i kada će se oni dogoditi.

$\checkmark$ Podijelite upitnike za ocjenjivanje.

$\checkmark$ Završna riječ/zahvala na dolasku.

$\checkmark \quad$ Skupite sve upitnike i materijale.

$\checkmark$ Raščistite radni prostor. 


\section{Nakon događanja - naknadne aktivnosti}

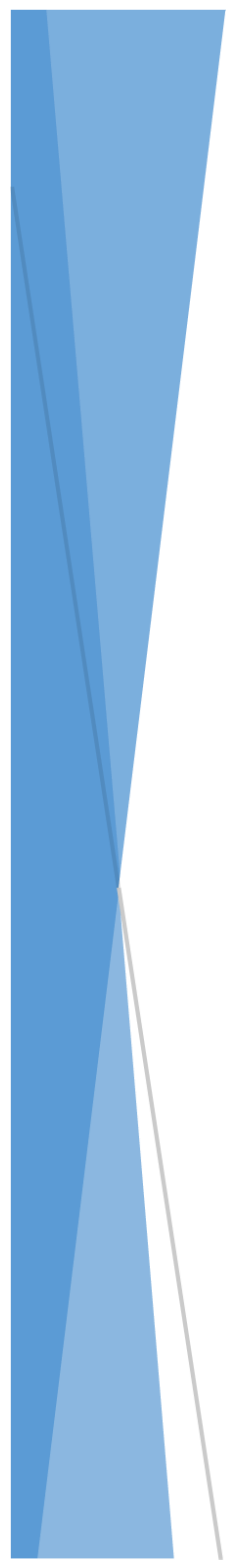

Bez obzira koliko je događanje bilo uspješno i sudionici zadovoljni, vrlo lako sve može propasti ako se ne pobrinete za prikladan nastavak događanja. Stoga je važno da se držite dogovorenih rokova kada ćete poslati obećane materijale $i$ informacije. Trebali biste kontaktirati sudionike 1-2 tjedna nakon događanja.

$U$ ovom poglavlju ukratko je sažeto ono što biste trebali poslati sudionicima događanja i zašto, te kako početi pripremati sljedeće događanje ili korak u postupku.

Nakon SNAP-SEE događanja, sudionici su primili nekoliko brošura putem e-mail-a: sažeto izvješće o događanju, snimku (interaktivne) rasprave, popis sudionika $i$ prezentacije. 


\section{Što treba poslati sudionicima događanja?}

Sudionicima biste trebali poslati:

$\checkmark$ Kratko izvješće o događanju sa prijepisom zabilješki s radionica - ostavite in zapisane riječima sudionika.

$\checkmark$ Objasnite kako ćete upotrijebiti rezultate radionice i njihove doprinose.

$\checkmark$ Također uključite i rezultate ocjenjivanja.

$\checkmark$ Priložite prezentacije koje su predstavljene na događanju, skenirajte popis sudionika i fotografije.

$\checkmark$ Informirajte ih o sljedećim koracima ili događanjima.

\section{Zašto?}

$\checkmark \quad$ Kako biste pokazali da cijenite njihova mišljenja i da ste pažljivo zabilježili sve što su govorili.

$\checkmark \quad$ Kako biste sudionike održali zainteresiranim i informiranim.

$\checkmark$ Sudionike trebate obavijestiti o tome što će se dogoditi s njihovim mišljenjima (koja su podijelili na radionici) ako želite da ponovo sudjeluju. To će pomoći svim sudionicima da osjete kako netko cijeni njihova mišljenja.

\section{Nakon događanja:}

$\checkmark$ Pošaljite izvješće $s$ događanja/radionice svim sudionicima (uključujući prezentacije i foto) i onima koji su bili pozvani, ali nisu mogli sudjelovati.

$\checkmark$ Pripremite priopćenje o događanju za medije.

$\checkmark$ Redovito informirajte sudionike te in uključite $u$ druga povezana događanja.

Kada događanje završi, trebate ga ocijeniti unutar svoje organizacije i tima za koordinaciju te ga sagledati iz perspektive cjelokupnog postupka:

$\checkmark \quad$ Jesmo li postigli svrhu događanja?

$\checkmark \quad$ Tko su bili sudionici? Jesu li predstavljali (ključne) organizacije dionika?

$\checkmark \quad$ Tko je nedostajao? Zašto? Što možemo učiniti kako bismo ih privukli u postupak?

$\checkmark$ Što ćemo učiniti s povratnim informacijama?

$\checkmark \quad$ Tko će pripremiti izvješće o projektu?

$\checkmark$ Trebamo li dodatne analize, informacije, itd.? Trebamo li se savjetovati s dodatnim stručnjacima kako bismo to saznali?

Kada krenemo razmišljati o sljedećem događanju, trebali bismo preispitati sve poduzete korake i procijeniti kako se sljedeći put aktivnosti mogu poboljšati (gdje je potrebno). 


\section{Zaključci i preporuke}

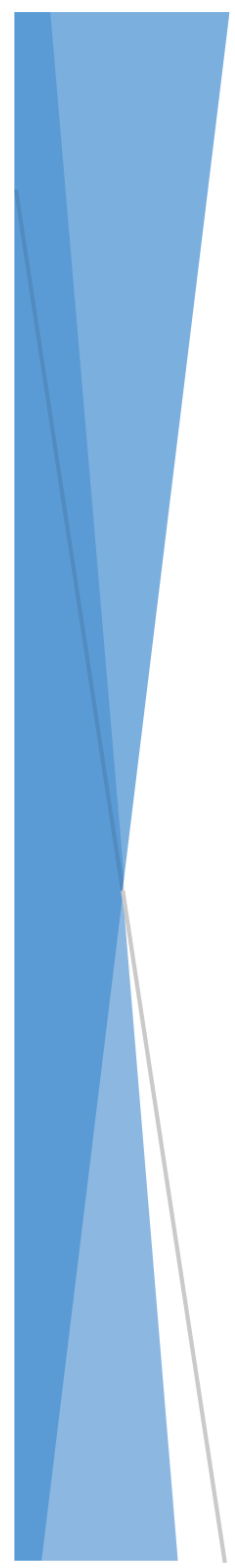

Ukratko, preporuke su sažete u svakom poglavlju. One daju ključne smjernice koje treba uzeti u obzir kada se planira postupak savjetovanja, provedba pojedine radionice ili upotreba pojedinih interaktivnih tehnika.

Preporuke se temelje na iskustvu partnera projekta SNAPSEE koji su održali savjetovanja, autora priručnika $i$ objavljenih radova. Snažno preporučujemo da pokušate koristiti predložene metode kako biste saznali njihove prednosti i putem stekli znanje. 
Svrha projekta SNAP-SEE bila je povećanje kapaciteta dionika i razvijanje alata za osiguranje održive opskrbe agregata u jugoistočnoj Europi. Dvadeset sedam partnera iz 13 država analizirali su postojeće stanje u planiranju agregata, razvijali smjernice za unaprjeđivanje postupka i dogovorili se o Viziji najbolje prakse za planiranje agregata u jugoistočnoj Europi.

Jedno od saznanja je da svaka država treba razvijati svoj plan za agregate ili mineralne sirovine za sljedećih 20 godina. Međutim, planiranje obavlja vlada i ne može se provoditi isključivo od strane partnera projekta. Alatni okvir (Toolbox) za planiranje agregata je rezultat iskustva rada na projektu i predstavlja prateću dokumentaciju svim zainteresiranim organizacijama koje se suočavaju s ovakvim izazovima. Nužno je uključiti dionike u postupak savjetovanja što je prije moguće. U ovom poglavlju su sažete ključne preporuke.

Prednosti savjetovanja s dionicima kao podrška najboljih praksi u održivom planiranju agregata

$\checkmark \quad$ Uključivanje dionika predstavlja različita mišljenja o agregatima - državnim tijelima, stručnjacima, industriji, nevladinim organizacijama i lokalnim zajednicama - omogućuje prikupljanje šireg znanja i iskustva te prepoznavanje boljih rješenja. Neophodno je saslušati razne mogućnosti $i$ razmotriti stajališta nekoliko ciljanih skupina želimo li postići dobitnu situaciju.

$\checkmark$ Vođenje postupka sudjelovanja u početku se može učiniti dugim i skupim, ali na kraju će rezultirati bolje informiranom odlukom sa širom potporom.

$\checkmark$ Savjetovanja su dobar način za motiviranje ciljanih skupina kako bi se provele najbolje prakse u planiranju agregata i razmotrila druga mišljenja dionika uključenih u postupak.

$\checkmark$ Dogovori postignuti sudjelovanjem svih dionika lakše je provesti.

$\checkmark$ Organiziranje savjetodavnih događanja dovodi do bolje suradnje između različitih institucija koje su nadležne za planiranje ili pogođene planiranjem agregata.

$\checkmark$ Rezultati također uključuju: povećanu svijest o važnosti planiranja, potrebu za pripremom državnog ili regionalnog plana/politike o mineralnim sirovinama i poticanje upotrebe sekundarnih agregata.

$\checkmark \quad$ Ljudi postaju umorni ako samo sudjeluju na beskorisnim događanjima. Ako ih pozovete, jasno recite svrhu i dodanu vrijednost kojom će dati doprinos događanju te što će dobiti.

\section{Planiranje postupka sudjelovanja s dionicima}

$\checkmark$ Moramo jasno definirati svrhu savjetovanja, što želimo postići, tko bi trebao sudjelovati i kako ćemo koristiti prikupljene informacije. 
$\checkmark$ Potrebno je informirati sudionike o svrsi, njihovoj ulozi te kako mogu utjecati na odluke.

$\checkmark$ Glavni cilj postupka bio je postići održivu opskrbu agregatima uključivanjem svih pogođenih ciljnih skupina.

$\checkmark \quad$ Ishod može biti: bolje razumijevanje postupka planiranja agregata, dogovor o rješenjima, povećanje kapaciteta pojmova SARM i SSM te dobrih praksi u drugim državama, povećana svijest o održivim pristupima te bolje poznavanje aktualnih podataka i metoda.

$\checkmark \quad$ Vrijeme i zasebne korake postupka potrebno je pažljivo odrediti kako bi se postigao opći cilj.

\section{Tko su dionici i kako ih uključiti}

$\checkmark \quad$ Svaki postupak savjetovanja ima različite ciljane skupine. Moramo pažljivo odrediti koje su skupine zadužene za donošenje odluka, a koje su uključene ili pod utjecajem postupka.

$\checkmark$ Glavne ciljane skupine u planiranju agregata su: državna tijela različitih sektora, industrija agregata, stručnjaci, lokalne zajednice i nevladine organizacije te šira javnost i mediji.

$\checkmark$ Potrebe različitih skupina dionika se razlikuju te ih moramo uzeti u obzir prilikom planiranja vrsta i opsega uključenosti. Neki će rado sudjelovati na cjelodnevnoj radionici, dok ćemo za druge morati organizirati kratki sastanak kako bi od njih prikupili bitne informacije.

$\checkmark$ Njihovi interesi i mišljenja dosta se razlikuju i mogu biti međusobno suprotna. Zato moramo pažljivo razmisliti na koji način možemo sa svima surađivati kako bismo izbjegli sukobe.

$\checkmark \quad$ Industrija je vrlo motivirana za suradnju te moramo paziti da je ravnopravno zastupljena. Bitno im je da državna tijela osiguraju stabilne i pravedne uvjete rada za njihovo poslovanje.

$\checkmark$ Stručne organizacije i stručnjaci iz različitih područja pružit će važne uvide u različite teme.

$\checkmark$ Predstavnici u području zaštite okoliša, nevladine organizacije i zajednice su također zainteresirani za uključivanje u dijalog od početka, tako da se njihovo mišljenje može uzeti u obzir. Iskustvo pokazuje da oni nisu „a priori“ protiv eksploatacije, ali prečesto su ostavljeni za posljednju fazu postupka.

\section{Planiranje događanja}

$\checkmark \quad$ Vrijeme za planiranje provedbe događanja je presudno. Pojedino događanje počnite planirati barem 6-8 tjedna unaprijed. Planiranje međunarodnog događanja potrebno je početi 6 mjeseci ranije. 
$\checkmark$ Pomno odaberite datum događanja, izbjegavajte zauzeta razdoblja, državne praznike, školske praznike ili velika sportska događanja.

$\checkmark$ Odaberite mjesto za događanje koje je prikladno vašim potrebama: pristupačno, primjerene veličine za planirani broj sudionika i dnevni red.

$\checkmark$ Odredite predstavnika tima za pripremu, članove tima i njihove uloge. Redovno provjeravajte napredak dodijeljenih zadataka.

$\checkmark \quad$ Jasno odredite svrhu svakog pojedinog događanja i kako je planirate postići - je li vaš cilj informiranje sudionika i potrebno vam je nekoliko prezentacija, trebate li prikupiti veliki broj ideja ili biste željeli postići dogovor?

$\checkmark$ Struktura događanja mora se uklopiti u gore navedene ciljeve - rasprava za okruglim stolovima, interaktivni rad u skupinama, prioriteti.

$\checkmark \mathrm{Na}$ temelju željene strukture događanja, trebate pripremiti prigodan program.

$\checkmark$ Stanke za kavu (i čak stanka za ručak) važne su, jer omogućuju neformalna okupljanja sudionika i razmjenu mišljenja.

\section{Tehnike za interaktivne radionice}

$\checkmark$ Rad u skupinama ima nekoliko prednosti, jer omogućuju većem broju sudionika uključivanje u raspravu i iznošenje svojeg mišljenja.

$\checkmark$ Tehnike se biraju na osnovu onoga što želimo postići - brojne ideje, opširne rasprave, određivanje prioriteta.

$\checkmark$ Dodatne informacije možete pronaći na: http://participationcompass.org/.

\section{Provedba događanja}

$\checkmark$ Pregledajte zadatke s timom prije početka.

$\checkmark \quad$ Budite opušteni i pozitivni. Vjerujte da ćete postići dobre rezultate.

$\checkmark$ Pripremite dvoranu u skladu s planom i omogućite najbolji mogući postupak sudjelovanja onima koji su posvetili svoje vrijeme vašem događanju.

$\checkmark \quad$ Ključ uspjeha su dobro pripremljeni i iskusni moderatori.

\section{Završetak događanja i naknadne aktivnosti}

$\checkmark \quad$ Na kraju događanja obavijestite sudionike o narednim radnjama.

$\checkmark$ Pošaljite sudionicima (i onima koji nisu mogli doći) zahvalnicu u roku 1-2 dana, izvješće s događanja i materijale u roku 1-2 tjedna.

$\checkmark$ Obavještavajte ih o cjelokupnom postupku i rezultatima.

$\checkmark$ Budete li pažljivo isplanirali postupak i događanje, to će vam osigurati uspješnu provedbu i zadovoljne sudionike. 


\section{Literatura}

Århus Convention: UNECE Convention on Access to Information, Public Participation in Decision-making and Access to Justice in Environmental Matters. http://www.unece.org/env/pp/treatytext.html

British Geological Survey (2006). Planning4Minerals: A Guide on Aggregates. http://www.bgs.ac.uk/planning4minerals/assets/downloads/86210 P4M A Gui de On Aggregates.pdf

Chalkiopoulou, F. \& Hatzilazaridou, K. (2011). How to achieve aggregates resource efficiency in local communities, a joint manual, for stakeholders' decision making on the local level, SARMa (SARMa - SEE/A/151/2.4/X). http://www.sarmaproject.eu

Chreighton, J. L. (2005). The Public Participation Handbook: Making Better Decisions Through Citizen Involvement. John Wiley \& Sons, Inc.

Dolinar, U. \& Kozinc, Z. (2013). Stakeholder involvement as a key factor for sustainable aggregates planning and management, Proceedings, 6th International Conference on Sustainable Development in the Minerals Industry (SDIMI), Milos, Greece.

Erricsson, M. \& Särkkä, P (2013). Socio-economic impact of the Finnish extractive industries. Proceedings, 1st International Conference on Sustainable Development in the Minerals Industry (SDIMI 2003), Milos, Greece, pp. 243-251.

Getzner, M. et al. (2010). People, parks and money. Stakeholder involvement and regional development: a manual for protected areas. Klagenfurt, Verlag Johannes Heyn.

Global Reporting Initiative (2002). Sustainability Reporting Guidelines.

International Council on Mining and Metals (2003). Community Development Toolkit. ICMM, London.

Korff, von Y. et al. (2010). Designing Participation Processes for Water Management and Beyond. Ecology and Society, vol. 15., No. 3.

http://www.ecologyandsociety.org/vol15/iss3/art1/

Marega, M. (2011). Guidelines on Stakeholder Engagement in Preparation of Integrated Management Plans for Protected Areas. NATREG project.

http://www.zrsvn.si/dokumenti/64/2/2010/Guidelines on stakeholder engage ment REC 1978.pdf 
MMSD (2002). Breaking new ground. Final report on the Mining, Minerals and Sustainable Development Project. IIED, London.

http://pubs.iied.org/pdfs/9084IIED.pdf

New Zealand Planning Institute (2013). Quality planning New Zealand.

http://www.qualityplanning.org.nz/index.php

Nielsen, K. (2003). Sustainable development indicators in the aggregate industry. A Norwegian perspective. Proceedings, 1st International Conference on Sustainable Development in the Minerals Industry (SDIMI 2003), Milos, Greece, pp. 285289.

Participation compass (2013). participationcompass.org

Participation Directive: Directive 2003/35/EC of the European Parliament and of the Council of 26 May 2003 providing for public participation in respect of the drawing up of certain plans and programmes relating to the environment and amending with regard to public participation and access to justice Council Directives 85/337/EEC and 96/61/EC.

Pound, D. (2008). Stakeholder dialogue, A good practice approach to participation. Dialogue Matters Ltd.

Softić, M., et al. (2011). Training Manual for Organisation of National Seminars within the DMCSEE project. DMCSEE (DMCSEE - SEE/A/091/2.2/X).

Šolar, V. S., Shields, D. J.,\& Zelič, U. (2012). Sustainable Aggregates Resource Management: experience learnt and shared within South East Europe. Ljubljana: Mining and Metallurgy Quarterly (RMZ - Rudarsko metalurški zbornik).

Šolar, S. \& Shields, D. (2011). The SARMa Project: enhancing sustainable aggregates resource management and supply in Southeast Europe. In: Martens, P. (ed.) Proceedings, $5^{\text {th }}$ Conference on the Sustainable Development in the Mineral Industry (SDIMI 2011). June 14-17, Aachen, DE. Essen, DE: RWTH Aachen University.

The Environment Council (2004). Good Practice for Stakeholder Engagement in the Aggregates Sector. http://www.sustainableaggregates.com/library/docs/ samp/l0138 samp 1 019.pdf

Tiess, G. (2001). General and International Mineral Policy. Focus Europe, Springer.

Tiess, G. \& Chalkiopoulou, F. (2011). SARM and SSM at the Regional, National and Transnational Level manual, SARMa (SARMa - SEE/A/151/2.4/X).

Van der Veen, P. \& Strongman, J. (2003). Sustainable development - The way forward for the mining industry, Proceedings, 1st Int/nal Conference on Sustainable Development in the Minerals Industry (SDIMI 2003), Milos, Greece, pp. 17-23. 



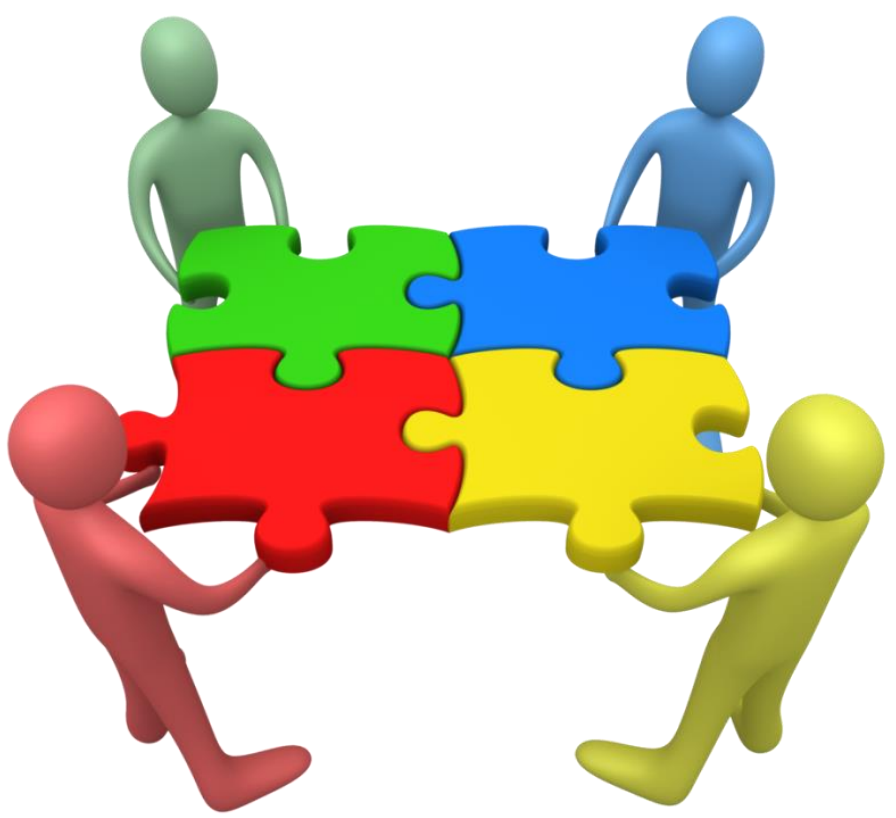

Održivo planiranje kamenih agregata u Jugoistočnoj Europi (SNAP-SEE) 